\title{
Over-Education and the Skills of UK Graduates
}

\author{
Forthcoming in the Journal of the Royal Statistical Society, Series A.
}

\author{
Arnaud Chevalier* \\ and \\ JOANNE LINDLEY
}

September 2008

\begin{abstract}
:
During the early Nineties the proportion of a cohort entering higher education in the UK doubled over a short period of time. This paper investigates the effect of the expansion on graduates' early labour market attainment, focusing on over-education. We define overeducation by combining occupation codes and a self-reported measure for the appropriateness of the match between qualification and the job. We therefore define three groups of graduates: matched, apparently over-educated and genuinely over-educated. This measure is well correlated with alternative definitions of over-education. Comparing pre- and postexpansion cohorts of graduates, we find with this measure, that the proportion of overeducated graduates has doubled, even though over-education wage penalties have remained stable. We do not find that institution type affects the probability of genuine over-education. Apparently over-educated graduates are mostly undistinguishable from matched graduates, while genuinely over-educated graduates principally lack non-academic skills and suffer a large wage penalty. Individual unobserved heterogeneity differs between the three groups of graduates but controlling for it does not alter these conclusions.
\end{abstract}

Key words: Over-education, Skills

JEL: J24, J31, I2

\footnotetext{
* Arnaud Chevalier, Department of Economics, Royal Holloway University of London, Egham, TW20 0EX, arnaud.chevalier@rhul.ac.uk, and associate at the Centre for the Economics of Education, London School of Economics, Geary Institute, University College Dublin and IZA, Bonn.

- Joanne Lindley, Department of Economics, University of Sheffield, 9 Mappin Street, Sheffield, S1 4DT.
} 


\section{Introduction}

Up to the Eighties, Britain had one of the lowest participation rates in higher education across OECD countries. Consequently, increasing participation in higher education became the mantra of British governments. The proportion of a cohort reaching higher education began to slowly rise during the early Eighties and increased rapidly towards the end of the decade. As illustrated in Figure 1, the proportion of a cohort participating in higher education doubled over a five year period, from $15 \%$ in 1988 to $30 \%$ by 1992 . This rapid expansion was caused by changes in both the demand and the supply of higher education. The reform of General Certificate of Secondary Education for example led to more individuals having the required qualifications for university, whilst the Education Act of 1988 allowed universities to expand. Additional reforms in the early Nineties led to the end of the separation between polytechnic institutes and universities and a large expansion in the former sector. The current governmental target is to attain a participation rate of $50 \%$ of a cohort experiencing higher education by 2010 and programmes to widen participation from disadvantaged social groups (Aimhigher) have been promoted. In a publicly funded system, the expansion in the number of graduates was only possible because of a large reduction in the unit cost of a graduate; from $£ 8,000$ in 1989 to $£ 5,000$ in 2000 (Department for Education and Skills, 2003).

A doubling in the flow of graduates over a short period of time is rather unique and has led to concerns about the employability of recent graduate cohorts. On the supply side, post-expansion graduates may have less human capital than pre-expansion graduates for a number of reasons. First, some graduates may have failed to develop appropriate skills whilst at university due to over-crowding and other quality issues associated with cost reductions. Second, in the face of increased competition to attract additional students, universities may have developed programmes with little academic content so that graduates are not obtaining skills that are demanded in the labour market. Third, admission standards may have been lowered in order to meet targets and consequently, universities may have accepted students from a lower part of the ability distribution.

Notwithstanding the supply effect, there have also been concerns that the employers' demand for graduates may have failed to increase in the same proportion as the supply. Due to the potential reduction in human capital of newer cohorts of graduates and 
disequilibrium in the labour market, the proportion of graduates employed in a job for which they are over-qualified may have increased dramatically.

The potential over-production of graduates has attracted a large literature which has reached somewhat contradictory conclusions. Whilst over-education has been prevalent, with up to 30 percent of graduates over-educated (see Sloane, 2003 or McGuiness, 2005 for recent surveys), the returns to higher education have not fallen over time (see Machin, 1999 and Dearden et al., 2002). However, most empirical evidence has been based on pre-expansion cohorts. One exception is Walker and Zhu (2005) who estimate that, for young graduates, the returns to degrees, as well as the probability of being in a professional/managerial occupation, have been declining in the later part of the Nineties.

Given the recent introduction of tuition fees into the English higher education system, an investigation into the extent and consequences of over-education has some policy interest. Since September 2006 most undergraduates at English institutions pay a fixed fee of $£ 3,000$ per year. These fees are not paid ex-ante by the student but are instead part of a subsidised loan to be reimbursed after graduation, conditional on an earning more than $£ 15,000$ per year. Consequently, if a large proportion of graduates remain in low paid occupations they will not be in a position to reimburse their loan fully, which will provide an additional fiscal cost to the tax-payers. Additionally, the results on the previous expansion in the number of graduates would be useful to judge the labour market consequences of reaching $50 \%$ of a cohort attending higher education.

The contribution of this paper is threefold. First, we compare various measures of over-education. The existing literature has been plagued with difficulties in defining overeducation. We follow an approach suggested by Chevalier (2003), based on occupation and self-reported satisfaction of the match between occupation and education to create a partially subjective measure which captures skills used in the job. We define three groups. The first group are matched graduates who are employed in a traditional graduate job i.e. a job that requires graduate skills, as defined by the 1991 Dictionary of Occupational Titles (DoT). This definition was provided by the United States Department of Labor and is based on the opinion of occupational analysts (see http://www.oalj.dol.gov/libdot.htm for details). Using this DoT definition, a traditional graduate job includes all managerial and professional occupations, as well as IT associate professionals, nurses and midwives. Secondly there is a 
group of apparently over-educated graduates who are not in a traditional graduate job but are satisfied with the match between their job and their education. The third group are the genuinely over-educated who are not in a traditional graduate occupation and are not satisfied of the match between their job and their education. We then compare this definition to alternatives used in the existing literature

Secondly, we analyse the early labour market experience of a sample that graduated at the peak of the higher education expansion period, namely the 1995 cohort of graduates. With our favoured definition, we find a reduction in the proportion of graduates employed in a traditional graduate job, compared to an earlier cohort from 1990. Additionally, we find that the relatively lower wages with respect to matched graduates (or wage penalty) experienced by genuine over-education remained stable across the two cohorts and increased by $15 \%$ for apparent over-education. Hence, whilst post-expansion graduates were less likely to be employed in traditional graduate jobs, most were found to be employed in a range of new jobs which nevertheless used their skills. Additionally, we find no change in the proportion of graduates reporting that a degree was needed to get their job. This is important since some commentators have questioned the rationale of the higher education expansion (Wolf, 2002).

Thirdly, since most of the literature on over-education implicitly assumes that qualifications equate to skills, we investigate whether the over-education wage penalty remains even after controlling for observable graduate skills or skill mismatch. We find evidence that genuinely over-educated individuals, but not apparently over-educated, lack 'graduate skills'; mostly management and leadership skills. Moreover, we address the issue of the endogeneity of over-education. Individual characteristics, such as motivation for example, that are not observed could be correlated both with over-education and earnings. Thus, the estimate of over-education effects in a wage regression would be biased. Assuming that these unobservable characteristics are fixed over-time, we approximate them with the residuals from a wage regression at an earlier period. As well as capturing individual unobservable characteristics that affect wages this variable also reflects the characteristics of the first job. In so far as these initial conditions have long-term consequences on labour market attainment it is important to control for them (Margolis et al. 2001). For example, entering the labour market during a recession depresses the first job wage but may also depress subsequent wages. Over and above observable skills, this unobservable measure is also found to be an important determinant of the probability of being over-educated seven 
years after graduation. Moreover, over-education impacts negatively on the wages of graduates, over and above skill levels which suggests that the penalty cannot be solely explained by a lack of skills but also reflects some job idiosyncratic characteristics. Including the residuals from first wage regression to limit the potential endogeneity of overeducation, indeed leads to a reduction of the wage penalty. Nonetheless even in the most extensive specifications, the wage penalties for over-education remain significant.

The paper proceeds as follows. The next section details some of the relevant literature, whilst the third section provides an overview of the data and presents some descriptive statistics. Section 4 discusses the empirical results for the incidence of overeducation and the determinants of earnings. The final section concludes.

\section{Literature Review}

The pioneering work on over-education by Freeman (1976) suggests that overeducation is a temporary phenomenon due to friction in the labour market. The over supply of graduates at one period triggers a reduction in the returns to education which eventually leads to a decrease in the number of graduates and a return to an equilibrium between the demand and the supply of graduates. The literature on over-education has concentrated on defining over-education and assessing its effect on wages; for extensive surveys see Groot and Maasen van den Brink (2000), Sloane (2003), or McGuiness (2005). This literature has documented the extent of over-education in a number of countries and reported a significant wage penalty associated with working in a job for which one is over-educated compared to individuals with the same level of education.

Most of the UK literature typically finds that $30 \%$ of graduates are overeducated. Battu et al. (2000) provide one of the most comprehensive studies of over-education. They found that on average one quarter of individuals are over-educated, based on 36 estimates. They also concluded that over-education did not increase in the early Nineties, despite the general increase in educational attainment. This result is supported by Groot and Maassen van den Brink (2000) whose meta-analysis of 25 studies found no tendency for a world-wide increase in the incidence of over-education, although they do say it has become increasingly concentrated among lower ability workers, suggesting that over-education is not solely due to 
mismatch of workers and jobs. Generally, studies show that the wage penalty associated with graduate over-education ranges between 11 and 30 percent for graduates.

Freeman's model also predicts that increased over-education should be associated with a decrease in returns to education. Machin (1999) and Dearden et al. (2002) find no reduction in the returns to education over time, which could suggest that over-education has remained stable despite the increase in the number of graduates. The lack of evidence supporting a decrease in the returns to a degree has been used to contest the extent of overeducation. However, since most of the studies estimating returns have been based on the stock of UK workers, out of which new graduates form only a small proportion, they may have underestimated the evolution of the returns over time. Focusing on young cohorts only, Walker and Zhu (2005) do indeed report lower returns for recent graduates compared to previous cohorts. Additionally, there is some evidence that over-education may be permanent at the individual level. Dolton and Vignoles (2000) found that 38\% of the 1980 cohort of UK graduates were over-educated in their first job and that $30 \%$ remained so six years later. Over a longer period there is also evidence that over-education is a permanent feature of some graduates' career (Dolton and Silles, 2003). This may be due to a decrease in cognitive ability when over-educated (De Grip et al, 2008).

It has been suggested that over-educated workers merely possess skills that are not demanded in the labour market. Hence, it is not just that they have less 'unobservable' skills, but they have more 'undesirable' skills. Consequently, a few studies have attempted to distinguish between a formal education mismatch (over-education) and mismatch between acquired and required skills. Allen and van der Velden (2001) used a 1991 survey of Dutch graduates to show that a mismatch between education and jobs does not necessarily imply a serious mismatch between available and required skills. Green et al. (2002) found that overeducation and skill under-utilisation involved a loss in wages. Similarly, Green and McIntosh (2007) found that among employees who are over-educated, less than half report having skills and abilities that they are not using in their job. These studies suggest that the apparent effects of over-education could be spurious and represent other unobserved 'ability' differences, over and above skill mismatch.

Büchel and Pollmann-Schult (2001), Bauer (2002), Chevalier (2003) and Frenette (2004) try to account for the endogeneity of over-education either by relying on panel data or 
by using statistical analysis to approximate fixed unobserved characteristics. After accounting for the unobserved heterogeneity, the wage penalty for over-education is reduced but a group of workers remained over-skilled for their jobs and suffered from substantial wage penalties.

\section{Data}

The main data were drawn from a survey of 4,502 UK domiciled individuals graduating in 1995 from 38 UK Higher Education Institutions. The survey was undertaken by the Institute of Employment Research (IER) at Warwick University in 2002/3, (see Elias and Purcell (2004b) for details). The participating institutions contacted their former students through their Alumni offices which makes the response rate difficult to calculate. However, Elias and Purcell (2004b) state "A series of tests of sample representativeness has been also undertaken, including attribute comparison with HESA (Higher Education Statistical Agency) population data and a telephone survey on non-respondents, all of which indicated that the educational and social characteristics of respondents are similar to those of the population from which they are drawn" (p4). Graduates were surveyed seven years after their graduation on aspects regarding their education, career paths and current economic situation. They represent around $2 \%$ of the total population of the 225,000 domestic UK students graduating in 1995 and exclude specialist (art and design or agricultural colleges) and Open University graduates. These data represent the first major study of post-expansion graduates. A similar postal survey dataset, conducted in 1996, is used for the 1990 cohort. This dataset is based on a survey of graduates undertaken by the University of Birmingham for the Higher Education Funding Council for England and the National Committee of Inquiry into Higher Education. The survey includes over 18,000 graduates from two academic years (1985 and 1990), from over 40 Higher Education Institutions (see Belfield et al. (1997) for details).

After eliminating respondents not working, not living in the UK or with missing values, our sample of the 1995 graduates is restricted to 2,484 employed graduates. This restriction leads to some potential selection bias as individuals with a greater probability of over-education may have been less likely to participate in a postal survey or be employed. However the lack of identification variables prevents us tackling this problem in our modelling. The criteria by which the respondents are selected are reported in Table A1 of Appendix 1. This shows that our final sample was marginally more successful at university 
and has experienced 0.3 less months of unemployment since graduation. We have restricted our sample to non-mature students, aged 25 or under at graduation, so that first job earnings do not reflect unobserved pre-university characteristics.

The data contains a wide range of information relating to respondents' personal and employment characteristics. These include socio-demographic questions such as sex, age, ethnicity, region of residence, parental social class; as well as human capital characteristics such as degree subject, class of degree, type of institution attended, and qualification held upon entry to higher education (where sample means are provided in Table A2 of Appendix 1). Employment questions were also asked and these included grouped annual gross salary, job satisfaction, firm-size, type of contract, sector and type of organisation. Throughout the paper we use hourly pay calculated as the midpoint of the annual gross salary categories divided by 52 times the weekly hours worked.

Crucially, information is collected on the respondents' current occupation at the four digit Standard Occupational Coding (SOC2000) level. We define 'over-education' as not being employed in a traditional graduate job, as defined previously. Following Chevalier (2003) we reclassify these into those who felt their qualifications were ideal for their current job (apparently over-educated) and those who thought their qualifications were very inappropriate (genuinely over-educated). Apparently over-educated workers use their graduate skills in their non-graduate job and therefore are not associated with skills underutilisation. This subjective definition allows us to capture idiosyncracies of the match. Acknowledging the heterogeneity of the graduate labour market, Elias and Purcell (2004a) also define five categories of job for graduates which we discuss later.

Figure 2 plots self-assessed qualification match against occupational group, where qualification match is measured on a 7-point scale between very inappropriate (1) and ideal (7). The occupation groups are defined using the one digit classification of the Standard Occupation Code 2000. The first group includes Managers and Administrators, the second Professional Occupations, the third Associate Professionals and Technical Occupations, the fourth Clerical and Secretarial Occupation. The remaining occupations are consolidated into a single group as few graduates are observed in these occupations. Perhaps not surprisingly, there is clear evidence of a dichotomy between Professional workers and everybody else. Workers employed in Professional occupations were much more likely to find their match 
ideal. Associate Professionals and Managers are not dissatisfied with their match but few claim it to be ideal, whereas those in Administration/Clerical and Other occupations had a greater propensity to see their match as very inappropriate. We define workers not employed in a graduate job as ‘apparently' over-educated if they ranked themselves between five and seven on the qualification match scale (satisfied with the match between education and job) and genuinely over-educated otherwise. Only individuals very dissatisfied with the match between their education and their job are classified as genuinely over-educated. We class all workers employed in a graduate job as matched. This provides a sample of 1,624 (65 percent) matched workers, 489 (20 percent) that were apparently over-educated and 371 (15 percent) that were genuinely over-educated.

Table 1 provides evidence that our measure of over-education defines three graduate groups. In its first panel we report up to 13 reasons for accepting the current job (more than one reason can be reported). Generally the reasons given are similar for matched and apparently over-educated graduates but largely different for genuinely over-educated. For example the later group was only half as likely as the others to report being exactly in the wanted job. The genuinely over-educated were also less likely to say that salary level, career development or conducting interesting tasks, were important reasons for accepting their current job and three times more likely to admit to accepting their job as an alternative to being unemployed or because it suited them for the short run. The only differences between the matched and apparently over-educated are that graduates from the latter group are more likely to report 'working for the employer of their choice', 'an interesting job' and state 'career developments' as reasons for accepting their current job. This suggests that apparently over-educated graduates may have adopted a stepping stone approach whereby they accepted a job with a specific employer in order to improve their long-term career prospects. Finally, the apparently over-educated were also more likely to accept a job because they thought it was interesting.

Panel B compares the self-reported time to learn how to do the job effectively across the three groups of graduates. This is measured in seven discrete categories. Using the category mid-points to define a continuous variable, the mean number of weeks to become fully proficient are 33, 28 and 21 for matched, apparent and genuine graduates respectively, where these differences are statistically significant. Over-educated workers are employed in jobs that are easier to learn, but there is a large difference between the two types of over- 
educated workers with the genuinely over-educated needing $25 \%$ less time to train for their current job compared to the apparently over-educated.

In panel $\mathrm{C}$ and $\mathrm{D}$, we report two satisfaction measures for career development and current job. Whilst there are only small differences in the satisfaction of matched and apparently over-educated graduates, the genuinely over-educated graduates are significantly less satisfied with both their career progress and their current job situation. Overall these statistics support the distinction between those who are not in a traditional graduate job but use their graduate skills and those who are pushed into jobs for which they are over-educated. The differences between matched and apparently over-educated graduates are more subtle and whilst they have the same level of job and career satisfaction, they do differ in their reasons to accept their current job and the time needed to train for this job.

In Table 2, we compare our proposed measure of over-education with other definitions that have been used in the literature. An alternative definition of over-education that is consistent for both cohorts is whether the possession of a degree was a requirement for obtaining their current job and this provides an objective measure for over-education (as used by Battu et al. 1999, 2000). However as one's career's progresses it may become unclear whether a degree is a requirement for the current job. For example, an individual promoted from a job where a degree was a requirement, may or may not report that the new job had an "implicit" requirement for a degree. So this statistic becomes a noisier measure of overeducation as experience in the labour market increases. Panel A reports some results using this definition. Only $27.9 \%$ of genuinely over-educated graduates are in jobs requiring a degree. However, the apparently over-educated graduates were only marginally less likely to be in a job that required a degree relative to matched graduates ( $76.1 \%$ compared to $81.7 \%$ ).

A popular measure of over-education defines over-educated workers as those who have more years of education than the mean occupational level plus one standard deviation (Verdugo and Verdugo, 1989). However, rather than using this approach directly, we use the winter quarter of the 2002 Quarterly Labour Force survey to calculate for each occupation (defined at the four digit level) with more than 10 observations, the proportion of the workforce that has a degree qualification. Overall, $20 \%$ of the workforce had a degree, but this proportion varies from 0 to $96 \%$ between occupations. In Panel $\mathrm{B}$, we report the proportion of respondents who are in an occupation where less than $30 \%$ of workers have a 
degree. Only $14 \%$ of the matched graduates are in such occupations; this proportion is $39 \%$ and $67 \%$ for apparently and genuinely over-educated respondents respectively. The differences are all statistically significant. Since this measure is based on stocks of workers it will not capture changes in graduate occupations over time. Thus it will over-estimate true over-education.

Our third measure for comparison is that proposed by Elias and Purcell (2004a). This measure improves on the previous definition since it allows for cohort differences in graduate jobs. Elias and Purcell compute the proportion of graduates in each occupation, separately for workers aged less than 35 and over 40. Using Labour Force Surveys from 2001 to 2003, they use these proportions to define four categories of graduate job. Traditional graduate jobs are those where the proportion of graduates in the older cohort is greater than $60 \%$. Modern occupations are defined as having more than $40 \%$ graduates in the older cohort and more than $50 \%$ in the younger one. New graduate jobs are those with more than $40 \%$ of graduates in the younger age group and at least a 10 percentage point difference between the older and younger cohort. Niche graduate occupations include jobs which "provide ample scope for the exercise of degree level skills and knowledge" (p5). They show that these graduate jobs differ in their skill usage and earnings. A drawback of this definition is the assumption that the skills required for a given occupation do not differ between workers. Our measure of over-education on the other hand, allows each worker to assess the appropriateness of their match.

Elias and Purcell's (EP) measure is reported in Panel C of Table 2. Again, there are large differences in the distributions between matched, apparent and genuinely overeducated. Both definitions classify a similar proportion of graduates as over-educated (11\% using EP and $15 \%$ in our case) however the measures are not the same. For example, only $42 \%$ of the genuinely over-educated are in a non-graduate job according to EP. This proportion is $1 \%$ and $21 \%$ for matched and apparently over-educated graduates respectively. Two thirds of apparently over-educated are in occupations that are new or niche graduate occupation while the majority of matched graduates are in traditional and modern occupation. This table confirms that apparently over-educated graduates are in different types of jobs than matched graduates, namely those occupations that have recently emerged as requiring graduate skills. 
Table 2 shows that our definition of over-education is broadly consistent with alternatives that have been used in the literature, but allows the critical distinction that the over-educated population is heterogenous. The three over-educated groups are distinct for all alternative definitions. All the alternative measures provide some measures of the suitability of an occupation to graduates and there is always a clear ranking with matched graduates more likely to be working in a graduate job. On all measures there is a clear distinction between apparently and genuinely over-educated graduates. Hence it is crucial not to aggregate over-educated individuals into one composite group, based on not being employed in a typical graduate job.

Regarding the change in over-education over-time, the only consistent definitions between the 1990 and 1995 cohorts, are that based on the match between education and occupation and that based on whether a degree was required for the job, since in the 1995 survey, occupation is only reported at the 2-digit level. The two definitions lead to different conclusions regarding the evolution of over-education over time. The definition based on individual perception of the match between education and occupation shows a considerable increase in the proportion of over-educated graduates compared to a study of the 1990 cohort by Chevalier (2003), with the proportions of genuine and apparently over-educated workers both doubling from 11 and 7 percentage points respectively. This increase in over-education incidence is also consistent with the findings of Walker and Zhu (2005) of reduced returns to degree for the most recent cohorts. Using the alternative definition of degree requirement, we find no change in the proportion of over-education between the 1990 and 1995 cohorts, at around 30 percent for both cohorts. The discrepancy could be due to the fact that degrees are now required in jobs that according to the dictionary of occupational titles are not graduate jobs; $72 \%$ of apparently over-educated graduates report that a degree was required to get their job (Table 2).

Uniquely, the 1995 survey also provides detailed information on observable skills, whereby each respondent was provided with a list of 13 skills; these included academic skills such as written and spoken communication, numeracy, computer literacy as well as more labour market oriented skills such as management and leadership. Respondents identify which of these skills were gained from their degree course. From this we were able to generate 13 binary variables for skills held. Additionally respondents were asked whether each skill was used 'not at all', 'some' or 'a lot' in their job. We grouped together 'some' and 
'a lot' to form one composite group. From this we generated a binary variable for mismatch between skills developed at university and skills 'used' in employment. If a respondent is in possession of a particular skill which is not being utilised we class this individual as 'overskilled' in that particular skill (where the variable over-skilled is equal to 1 if the individual had that skill but did not use it in their job and zero otherwise); similarly if a respondent is using a skill that was not developed from their degree programme we classify that respondent as ‘under-skilled'.

The skills developed at university variables can be seen as proxies for the skills that the respondent holds. However, directly asking individuals whether they possess a given skill could be correlated with over-education status. For example, an over-educated worker may become despondent and report lower skills. However, the questions are whether the skills were developed at university' and 'whether they are used in the current job'. As a robustness test, we cross tabulated the distribution of Advanced IT or software skills with self-reported intensity of computer use in the job. If we believe that over-educated individuals are despondent we should observe discrepancies between the self-reported use and the selfreported skill level. We compute these statistics for all graduate groups and do not find significant differences between them. Hence, at least for this skill, there is no reason to believe that over-educated workers under-reported their skill level.

Table 3 reports the self assessment of skills developed on the 1995 degree course by over-education category. Matched graduates are 10 percentage points more likely to report technical skills such as IT and numeracy than genuinely over-educated graduates whilst more over-educated individuals have written communication skills. Larger differences in skills level are observed for non-academic skills (entrepreneurial, management and leadership). These are often the skills considered crucial to succeed in the labour market and for which genuinely over-educated individuals seem to be far less well equipped. Genuinely overeducated graduates are between 11 and 17 percentage points less likely to have developed these skills at university. The expansion of higher education has thus not lead to the creation of under-skilled graduates, at least as far as academic skills are concerned. This is consistent with the fact that most additional graduates found a job that uses their skills.

In the second panel of Table 3, skill mismatches represented by the difference between skills developed at university and skills used in the job (overskilling) are shown by 
over-education category. For example $0.7 \%$ (11 individuals) in the matched group had problem solving skills that were not being used in their job. In general the match between skills developed and skills used is rather good, with only 'research skills' and 'foreign languages' being substantially under-used. Note also that 'entrepreneurial', 'teamwork', 'management' and 'leadership' skills were always fully deployed. It is for this reason that no information is given for these skills in the lower half of Table 3. Despite generally lower level of skills, over-skilling was more prevalent amongst the genuinely over-educated, compared to the other two categories. For the genuinely over-educated, 'research', 'creativity' and to a lesser extent 'written communication' and numeracy skills were also significantly more likely to be reported as under-used.

Despite the expansion of higher education the differences in academic skills held across groups are small which suggests that most graduates developed academic skills whilst at university. However, for genuinely over-educated graduates these skills are under-used in the current job. This does not necessary imply that these graduates have acquired lower quality skills but simply that their skills are not in demand, as Green and McIntosh (2007) suggested. Moreover, based on these self-reported measures, genuinely over-educated graduates lack labour market related skills and could be at a serious disadvantage compared to their peers. The reason for the shortage of skills mostly obtained through extra-curricular activities is unclear. Matched and apparently over-educated graduates only differ on a few skills.

In addition to these self-reported tangible skills, we investigate differences in unobservable characteristics. The residuals from a regression of first job earnings on socioeconomic and employment characteristics at the time of the first job, are used to proxy unobservable characteristics of graduates. A detailed discussion of the procedure is provided in Appendix 2. The 'first wage' residuals represent the unobserved component of the individual wage after controlling for a set of characteristics. Here the confounding factors controlled for are socio-economic characteristics such as gender, age, ethnicity and parental social-class, and education characteristics such as type of school attended, A-level score, class and subject of degree as well as the type of higher education institution attended. We also include dummy variables for the skills acquired at university and the location of employment. These 'first wage' residuals measure intangible characteristics that are potentially observed by the employer such as motivation and punctuality, but they also 
incorporate an element of 'fortune', reflecting the conditions of labour market entry that may have affected earnings permanently or at least for the period of time covered by the dataset. Given that we control for skills obtained from the degree, this residual term is by construction uncorrelated to the observed skills. It measures all unobserved characteristics that determined the first job wage but were not included in the model. Throughout the paper we refer to these characteristics as unobserved characteristics but they incorporate characteristics of the individual as well as the initial conditions when the individual incorporated the labour market; we are not able to distinguish between the two components.

The results for the 'first wage' equation are given in Appendix 3. Most of the estimates have the expected sign. To simplify their interpretation the residuals are normalised to have a mean of 0 and a standard deviation of 1 . Figure 3 , compares the distribution of the normalised residuals separately across over-education groups. These differ for the three groups since the distribution is normal for the matched and apparently over-educated graduates while it is under-dispersed for the genuinely over-educated. Moreover, the mean fluctuates from 0.095 for the matched graduates, to -0.127 for the apparently over-educated, and -0.255 for the genuinely over-educated, with all differences being statistically significant. Hence apparently and genuinely over-educated graduates differ from matched graduates in some unobservable component that we might attribute to intangible skills and fortune.

\section{Results}

So far, the description of the raw data suggests that genuinely over-educated workers are less skilled (especially in labour market skills) and additionally that there may be some element of mismatch between the skills these graduates hold and those in demand from employers. Moreover, the over-educated appear to have less favourable unobservable characteristics, on average. Consequently, we investigate ceteris paribus the incidence and consequences, in terms of current wages, of over-education. Details of the methodological procedures, terminology and details of the interpretation to be given to the reported results are provided in Appendix 2.

\subsection{Incidence of over-education}


The determinants of over-education are estimated using a multinomial logit. Table 4 reports the marginal effects on the probabilities of overeducated response categories estimated at the sample means of explanatory variables for all the definitions of overeducation that have been assessed in Table 2. First we comment on the results for Model (1) in Table 4 for our favoured definition of over-education. The omitted response category is matched to graduate job. The marginal effect on this category could be inferred from the fact that marginal effects across all categories sum to zero. Sex and age do not significantly affect the probability of over-education. Academic credentials have only limited impact on the probability of over-education; a higher A-levels score reduces the probability of genuine over-education but only by 0.2 percentage point for each A-level point and surprisingly the class of degree is irrelevant. The type of institution however impacts on the labour force attainment; attending a 'new university' rather than an 'old university' increases the probability of being apparently over-educated by 5 percentage points but is not associated with genuine over-education. This is consistent with the idea that 'new universities' offered degrees in subjects leading to non-traditional graduate occupations but for which 'graduate skills' were nonetheless required. Hence it is not the case that graduates from these institutions were unwanted in the labour force. A post-graduate qualification reduces the probability of genuine over-education either because it provided graduates with additional skills or because it represented a signal of skills valued by employers. Different subject of studies protect against over-education. Compared to social science graduates, law and education graduates are significantly less likely to be apparently over-educated. Surprisingly, medical and related studies, as well as business graduates are the most likely to be apparently over-educated. More vocational subjects and mathematics appear to protect against genuine over-education. Parental social class is never found to be related to over-education but respondents whose parents were not working are more likely to be genuinely over-educated, maybe because these students have shorter search period due to lower wealth. The type of school attended is not significantly related to over-education and is therefore not reported in the table. These suggest that parental and social networks are not an important factor in obtaining a matched position.

Most academic skills do not affect the incidence of over-education after controlling for a wealth of educational variables. Only written skills increase the probability of apparent over-education by 9 percentage points. This skill increases the probability of apparent overeducation as it is likely to have been developed in subjects that have seen a large expansion in 
the number of graduates. So much so that not all graduates with written communication skills are able to find a traditional graduate job and some have to work in upgraded job. More professional skills (such as entrepreneurial, management and leadership) significantly reduce the probability of being genuinely over-educated. For example, having leadership skills reduces the probability of genuine over-education by 10 percentage points. This effect is as large as, for example, having a $\mathrm{PhD}$. So clearly non-academic skills matter in predicting overeducation, and genuinely over-educated graduates have relatively less of these.

If unobserved characteristics, such as motivation, are positively correlated with any of the controls included in the model, these estimates would be biased upwards. To limit this endogeneity bias we include our measure of unobserved skills. As explained above, the residuals from the first job earning equation capture all the characteristics of an individual, including job characteristics that affect wages over and above the included control variables. Hence including the residuals proxies time fixed effect unobservable characteristics. Improving the unobservable component by 1 standard deviation reduces the probability of apparent and genuine over-education by 2.9 and 3.7 percentage points respectively. In a market over-supplied with graduates, evidence suggests that employers were able to recruit and retain graduates with desirable skills.

In the rest of this Table, we show the robustness of our results to different measures of over-education. Model (2) reports the marginal effects of the probability of being overeducated when over-education is defined as being in an occupation with less than $30 \%$ graduates. Model (3) uses whether a degree was needed to obtain the current job. The remaining four columns report Model (4), the effects for each category of jobs defined by Elias and Purcell. The omitted reference response category for this model is employed in a traditional graduate job. The results are mostly consistent for all definitions. Subject of studies, post-graduate qualifications, non-academic and unobservable characteristics are always needed to avoid being in a non-graduate job regardless of how this is defined, but academic skills have little additional explanatory power.

In Table 5, we report further robustness checks as well as comparisons with the preexpansion cohort. The first specification only includes pre-university characteristics, as well as age, gender, ethnicity, school type and social background which are thought to be exogenous. None of the previous conclusions are altered, and we report that pre-university 
credentials are uncorrelated with over-education. Adding university characteristics, we still find that degree grade is not statistically significant, and that Nineties university graduates are 4.5 percentage points more likely to be apparently over-educated. Models with interactions between institution and degree grade, as well as degree grade and subjects were also estimated but are not reported here. Joint F-tests of interaction terms between degree class and institution types were not significant and thus it seems the probabilities of over education for various degree classes are not significantly different across various institution types. However, joint tests of interaction terms between degree grade (recoded as graduating with a First or a upper second) and subject were significant but none of the interaction terms were significant individually. Finally, the last model for the 95 cohort includes the proxy for unobservable characteristics. Compared to the model presented in Table 4, the specification does not include any characteristics associated with current jobs or skills. However, the conclusions are broadly similar.

Using the last specification, we replicate the analysis for the pre-expansion cohort. The main differences between the two cohorts are as follows. First, individual unobservable characteristics and initial job market fortune, as proxied by the first wage residuals, is an important predictor of current over-education status for the 1995 cohort but not for the preexpansion cohort which is consistent with an increased competition for obtaining a job that uses graduate skills (Thurow,1975). Second, graduating from a new university has no substantial affect on the probability of being genuinely over-educated. However, for the 1995 cohort, graduates from the new universities were 5 percentage points more likely to be apparently over-educated. This may be related to differences in the type of degrees provided by these institutions which may be more appropriate for non-traditional graduate jobs; so that graduates from new universities are as likely to be found in jobs requiring graduate skills but less likely to be a traditional graduate job.

To summarise, there is no evidence that new university graduates are of a lower quality than graduates from a traditional university, although they are more likely to be apparently over-educated suggesting that a degree from these institutions may develop skills more appropriate for non-traditional graduate jobs rather than traditional graduate occupations. Subject of degree remains the most important determinant and there are large differences in the probabilities of over-education across subject areas. Academic skills have a marginal impact on the propensity for over-education even when not controlling for subject 
of degree (this specification is not reported here). Management and leadership skills substantially reduce the risk of genuine over-education. Moreover, individual unobservable characteristics reduce both apparent and genuine over-education.

\subsection{Over-education, skills and earnings}

Figure 4 reports the hourly pay distributions for the three groups of graduates. These are almost identical for matched and apparently over-educated graduates confirming that the latter group is using graduate skills in the labour market. This is an important test for our definition as one could have argued that low skill graduates could also have reported being satisfied with the match between their education and their skills and thus wrongly be defined as apparently over-educated. Genuinely over-educated graduates earn on average almost $£ 3$ less than matched graduates (or $20 \%$ less at £11.40). The distribution of hourly pay is similarly shaped for genuine over-educated and matched graduates but is shifted to the right for the latter. This suggests that average pay differences are not due to a large tail of unfortunate individuals.

The determinants of log hourly pay 6/7 years after graduation for the two study cohorts are provided in Table 6. We estimate a Mincer equation as described in Appendix 2. This includes as controls: gender, social class of parents, ethnicity, the type of schools attended, pre-university credentials, type of higher education institutions, degree grade, subject of degree, additional qualifications. We also include employment characteristics such as quadratic functions of months of employment and unemployment since graduating, size of employers, and region of residence.

All the coefficients have the expected economic interpretation and therefore are not discussed in detail here. For the base model (1) the wage penalties for the 1995 cohort are 0.07 and $0.23 \log$ points for the apparently and genuinely over-educated respectively, compared to matched graduates. That is, over-educated graduates earn less than their peers who are in a matched job, on average. More parsimonious models which included only preuniversity, or only university covariates were also estimated. These models are not reported in Table 6, as no difference in the estimated coefficient was found for genuine over-education while the estimate on apparently over-education dropped to $-0.02 \log$ point in the preuniversity specification. It is important to note that we do not estimate the return to years of over-education but only compare earnings between graduates. The wage penalty for genuine 
over-education is identical to the one found for the pre-expansion cohort even though the probability of being genuinely over-educated doubled between the two cohorts. In the base model, the wage penalty for being apparently over-educated, at $0.07 \log$ points, has increased by only $0.02 \log$ points compared to the estimate for the 1990 cohort. As reported in EP, new graduate jobs pay less than traditional graduate jobs.

The estimates on over-education could be biased away from zero by endogeneity since unobservables correlated with a greater probability of over-education are likely to be negatively correlated with income. The unobserved characteristics proxy is highly significant; an increase by one standard deviation in unobserved skills increases the hourly wage by 0.07 $\log$ points and reduces the wage penalty by $20 \%$ and $10 \%$ for apparent and genuine overeducation respectively (model (2), Cohort 1995). Hence the over-education wage penalty cannot be attributed solely to lower unobservable characteristics relative to matched individuals. The point estimates of the return to unobserved skills are identical between the two cohorts. The wage penalty for genuine over-education decreased by 0.008 log point between the two cohorts but the one for apparently over-education increased by the same amount or $15 \%$. Despite the doubling of the over-educated population, the wage penalty for being over-educated has not substantially increased between the two cohorts. This suggests that employers have created new positions in traditionally non-graduate occupations in order to utilise the skills of the new graduates (see also Mason, 2002). Additionally, we test whether the impact of unobserved skills are identical for the three groups of graduates by introducing an interaction between over-education status and unobserved skills. These interactions were not found to be significant and are therefore not reported here.

To test whether the over-education wage penalty stems from a lack of skills, we include all the 13 skills developed at university as covariates. Table 4 suggests that academic skills are poor predictors of over-education. Not surprisingly then, the introduction of these skills in model (3) in Table 6 does not affect the estimates on over-education. In fact, as we control for a wealth of academic credentials, most academic skills are still not significant in the wage equation. Employers favoured graduates with entrepreneurial and management skills, both increasing hourly wage between 0.007 and $0.010 \log$ points. However, the introduction of labour market skills only marginally reduces the penalty for being overeducated compared to the base model (1). 
Including both observed and unobserved skills (model (4)) reduces the penalty for over-education to 0.05 and $0.18 \log$ points for apparent and genuine over-education respectively. Hence, we reject the assumption that being over-educated is solely due to a lower level of skills amongst over-educated graduates. It is nonetheless possible that the unobservable characteristics proxied by the first wage residuals are not fixed over time. For example a worker may lose motivation if career progression does not match initial expectations.

Model (5) adds measures for over and under skill utilisation as defined previously. The results show that only the under-skill dummies were jointly significant. This is mainly as a consequence of the large positive premium for basic computer literacy and research skills. These measures of over- and under-skilling do not reduce the wage penalty for being overeducated and are thus uncorrelated to the over-education status.

Finally we consider whether over-education is simply capturing idiosyncratic characteristics of the job. Model (6) includes contract type and sector, whilst model (7) also adds travel time, responsibility for planning work, computer use, promotion prospects, job satisfaction and satisfaction with career development. All these characteristics may be caused by over-education and might thus be considered endogenous. Their inclusion would thus lead to an underestimation of the wage penalty associated with over-education. Despite these additional controls being jointly significant they only have a limited effect on the overeducation wage penalties. This suggests that the over-education penalty is not due to a precarious employment situation, whereby individuals are accepting a temporary position in order to obtain a more suitable job, or compensating differentials, whereby workers trade lower pay for better working conditions. Including all job characteristics reduces the genuine over-education penalty further to around $0.13 \log$ points.

In Table 7, we compare the wage effect of over-education using our measure to various alternative definitions from the existing literature. To do this, we use the specification that includes unobserved skills (models of type (2) in Table 6), although models without this variable do not differ in terms of the over-education penalty. The first alternative measure is whether a degree was required to obtain the current job. This definition is available both for the 1990 and the 1995 cohorts. For the pre-expansion cohort we find a penalty for being over-educated reaching $0.11 \log$ points increasing to $0.13 \log$ points for the post-expansion 
cohorts. Thus according to this definition the pay gap for over-education increased by $17 \%$ between cohorts, similar to the $15 \%$ found for our favoured definition in Table 6 . Defining a graduate job as having more than 30 percent of the workers with a degree, the wage penalty for being over-educated is $0.12 \mathrm{log}$ points for the 1995 cohort. These two definitions provide a wage penalty for over education which is consistent with the weighted average of the wage penalties for apparent and genuine over-education (0.12 log points). In the final model overeducation is measured by dummy variables defined according to the EP classifications. The only significant wage penalty is for individuals in non-graduate job, for which the pay penalty reaches $0.19 \log$ points, slightly less than the one estimated for genuinely overeducated graduates. The difference between EP and our measure is that for the former definition there is no significant wage differential between all jobs that require some graduate skills, whilst for the latter definition a fall in earnings of 0.06 log points for apparently overeducated is found. These results support the idea that the wage penalty for over-education is heterogenous and that it is crucial to distinguish between graduates who are not in job that require graduate skills (for whom a large penalty around $0.20 \mathrm{log}$ points is found) and graduates who are not in typical graduate jobs but in an occupation where they utilise their graduate skills, for which we estimate no or a small penalty depending on the definition used.

In short, comparing the 1990 and 1995 cohorts shows that the wage penalty for over-education has only marginally increased. Given that the proportion of graduates not in a typical graduate job doubled over this period, such stability suggests that employers have upgraded jobs to make use of the available human capital. This has led to the creation of new positions with competitive wages and consequently we should not consider apparently overeducated graduates as being over-skilled for their jobs. In this sense, apparent over-education is not a mismatch. The financial situation of the genuinely over-educated has also remained stable but at a much lower level. Even accounting for all skills, these graduates earn between 13 and $23 \log$ points less, on average, than other graduates.

\section{Conclusion}

In the early Nineties, the proportion of the cohort entering higher education in the UK doubled over a 5-year period. As a consequence of this rapid expansion doubts have been raised about graduate quality, as well as the capacity of the labour market to absorb the influx. This paper focuses on a post-expansion cohort of graduates. When over-educated 
individuals are split into two groups; namely those who think that their current job is appropriate for their education (defined as apparently over-educated) and the rest of graduates in non-traditional graduate jobs, the two groups differ substantially, in terms of the reasons for accepting the current job, their observed and unobserved skills as well as their pay. Our definition of over-education is highly correlated with more objective and statistical measures which do not capture job match idiosyncrasies. We show that the probability of overeducation has doubled compared to the pre-expansion cohort, reaching as much as 35 percent with both genuine and apparent over-education increasing in equal proportions. Using alternative definitions of over-education such as whether a degree was required to get the job, the proportion of over-educated workers has remained stable at $30 \%$ for the two cohorts. The discrepancy highlights that the labour market has changed and that non-traditional graduate jobs have been upgraded to make use of the additional supply of graduates. The population of concern is the genuinely over-educated, who are in jobs that do not match with their graduate skills.

The first unique contribution of this paper is to compare the determinants of overeducation pre- and post-expansion. They have remained fairly similar. We find no evidence that graduates from new universities have "worthless" degrees as they have the same probability of being genuinely over-educated as other graduates. They are nonetheless more likely to be apparently over-educated maybe due to the specificities of their degrees. There is heterogeneity in the probability of over-education depending on the subject of degree, but most other academic credentials only have a marginal effect. The impact of non-observable characteristics has also increased more than 10 times suggesting that employers have become more selective in attributing jobs in a market abundant with new graduates.

Secondly, we assess whether over-education stems from heterogeneity in the skills of graduates. We find limited evidence that the over-educated (genuine and apparent) lack academic skills. So the expansion of higher education was not associated with a large heterogeneity in skills developed between graduates. The main skill differential between the three groups of graduates is that the genuinely over-educated had less management and leadership skills. Using the residual calculated from the first job wage equation to proxy time fixed unobservable characteristics, we find that over-educated graduates possess significantly less of these, on average. Moreover, unobserved characteristics and labour market skills, especially entrepreneurial, management and leadership largely reduce the risk of genuine 
over-education. Overall, over-education is not associated with a shortage of academic skills but is correlated with reduced labour market skills and unfavourable unobserved characteristics.

The third contribution is the evaluation of the effect of over-education on wages for the two cohorts and different definitions of over-education. After controlling for a wide array of educational characteristics, academic skills have a limited impact on wages for this population of your graduates, maybe due the small variance in skills. Labour market skills, which genuinely over-educated individuals lack, are on the other hand rather important; having management skills, for example, increases wages by $0.10 \log$ points. Unobserved characteristics similarly play an important role. A one standard deviation increase in unobserved characteristics leads to a pay gap of $0.07 \log$ points. Policies to improve the development of non-cognitive skills amongst students could therefore have a large impact on the labour market achievements of graduates. Genuine over-education leads to a reduction in hourly pay of $0.21 \log$ points even after we proxy unobserved heterogeneity. This estimate is almost identical for the two cohorts. For the apparently over-educated, the pay gap is only $0.06 \log$ points in our favoured model. This suggests that firms have 'skill upgraded' nontraditional graduate jobs in response to the increased skills available. As suggested by Elias and Purcell (2004a) the labour market has become more fragmented, thus defining overeducation solely as not being in a traditional graduate job would severely over-estimate the extent of over-education. A third of the over-education wage penalty can be explained by differences in observed and unobserved skills. For genuinely over-educated graduates, the wage differential is equivalent to the returns to a degree for this cohort (Walker and Zhu, 2005). These individuals may nonetheless enjoy returns to their degree. First, they may be able to obtain a graduate job eventually, even if Dolton and Vignoles (2000) have showed that this probability decreases rapidly a few years after graduation. Second, they may enjoy non-financial returns to education.

Some commentators (Wolf, 2002) have questioned policies expanding higher education. There has been doubt over whether the labour market could absorb such a rapid supply of new graduates. Our results suggest that the bulk of new graduates are in jobs matching their skills, but there is indeed some wastage, given that $11 \%$ to $15 \%$ of graduates are in jobs that do not require graduate skills and suffer a wage penalty that almost eradicates the financial benefit of higher education. We now do a simple back of the envelope 
calculation to assess the order of this wastage. The expansion led to an additional 100,000 graduates per year to 220,000 . A rate of $15 \%$ over-education post expansion implies that 33,000 graduates are not using their graduates skills, compared to the 8,400 pre-expansion. The labour market thus absorbed the majority of the additional graduates, mostly by upgrading non-traditional jobs. Apparently over-educated workers are mostly indistinguishable from matched graduates on observable characteristics, even though they suffer from a wage penalty of 0.06 log points. As for genuinely over-educated graduates, they appear not to suffer from a lower quality university experience but do lack non-academic skills (observed or not) which are necessary to succeed in the labour market. Since current policies have lead to increasing higher education fees, the rationale for this group of individuals to invest in higher education may have been reduced. This also suggests a potential fiscal shortfall since such individuals may not be able to repay their student loans, adding to the future burden of British tax payers. However, since we only observe earnings at two points in time we cannot realistically calculate the expected life time earnings of these graduates. The most we can say is that in 2002 , around $7 \%$ of graduates were earnings less than $£ 15,000$ per year and that $25 \%$ of genuinely over-educated graduates were in this category compared to less than $4 \%$ for the other two groups. This suggests that the increased future burden on society for the expansion of higher education may be substantial.

\section{Acknowledgments}

The data for the 1995 cohort was made available by Peter Elias (University of Warwick). Details can be found on http://www2.warwick.ac.uk/fac/soc/ier/research/completed/7yrs2/ . We are grateful to Steve McIntosh for his comments and would also like to thank participants at the Department of Work and Pension Economic Group Annual Conference (Canterbury), Educational Outcome Workshop (Milan) and European Society of Labour Economics (Prague) for valuable comments. We also want to thank the two referees and the editor for their pertinent and constructive comments. All remaining errors are solely our own. 


\section{References.}

Allen, J.. van der Velden, R. (2001) Educational mismatches versus skill mismatches: effects on wages, job satisfaction, and on-the-job search. Oxford Economic Papers, 53, 3, 434452.

Battu, H., Belfield, C. and Sloane, P. (1999) Over-education among graduates: a cohort view. Education Economics, 7., 21-38.

Battu, H., Belfield, C. and Sloane, P. (2000) How well can we measure graduate overeducation and its effects? National Institute of Economic Review, 171, 82-93.

Bauer, T. (2002) Educational mismatch and wages: a panel analysis. Economics of Education Review, 21, 221-9.

Belfield, C., Bullock, A., Chevalier, A., Fielding, A., Siebert, W., and Thomas, H. (1997) "Mapping the Careers of Highly Qualified Workers", HEFCE Research Series, M10/97

Büchel, F. and Pollmann-Schult, M. (2001) Over-education and skill endowments. The role of school achievement and vocational training quality. 'Institute for the Study of Labor (IZA), Bonn' Discussion Paper number 337 (downloadable from http://www.iza.org/).

Chevalier, A. (2003) Measuring over-education. Economica, 70, 3, 509-531.

De Grip A., Bosma, H., Willems, D., and van Bostel, M. (2008) "Job-worker mismatch and cognitive decline", Oxford Economic Papers, 60, 237-253

Dearden, L., McIntosh, S., Myck, M. \& Vignoles A. (2002) The returns to academic and vocational qualifications in Britain. Bulletin of Economic Research, 54, 3, 249-274.

Department for Education and Skills (2003) White paper on the Future of Higher Education, Her Majesty Stationary Office

Dolton, P.J. and Silles, M. (2003) The determination and Consequences of Graduate Overeducation, in F. Büchel, A. de Grip and A. Mertens (eds), Overeducation in Europe, Current Issues in Theory and Policy, Edward Elgar.

Dolton, P.J. and Vignoles, A. (2000) The incidence and effects of over-education in the graduate labour market. Economics of Education Review, 19, 2, 79-198.

Elias, P. and Purcell, K. (2004a) SOC (HE) A classification of occupation for studying the graduate labour market. Institute for Employment Research, Research Report 6. http://www2.warwick.ac.uk/fac/soc/ier/research/completed/7yrs2/rp6.pdf

Elias, P. and Purcell, K. (2004b) Seven Years on: Graduate Careers in a Changing Labour Market, Higher Education Careers Services Unit http://www2.warwick.ac.uk/fac/soc/ier/research/completed/7yrs2/seven_years_on.pdf

Freeman, R.B. (1976) The Overeducated American, New York: Academic Press

Frenette, M. (2004) The overqualified Canadian graduate: the role of the academic program in the incidence, persistence, and economic returns to overqualification. Economics of Education Review, 23, 29-45

Green, F., McIntosh, S and Vignoles, A. (2002) The utilization of education and skills. Evidence from Britain. The Manchester School, 70, 792-811. 
Green, F. and McIntosh, S (2007) Is there a genuine under-utilisation of skills amongst the over-qualified? Applied Economics, 39, 427-439.

Groot, W. and Maassen van den Brink, H. (2000) Over-education in the labor market: a metaanalysis. Economics of Education Review, 19, 149-58.

Machin, S. (1999) Wage inequality in the 1970s, 1980s and 1990s. In Gregg, P. and Wadsworth, J. (eds), The state of working Britain. Manchester, Manchester University Press, 185-205.

Margolis, D., Simonnet, V, and Vilhuber, L. (2001) Early Career Experiences and Later Career Outcomes : Comparing the United States, France and Germany, Quarterly Journal of Economic Research. 70, 31-38

Mason, G. (2002) High skills utilisation under mass higher education: Graduate employment in service industries in Britain. Journal of Education and Work, 15, 427-456

McGuinnes, S. (2005) Overeducation in the Labour Market, Journal of Economic Surveys, 20, 387-418

Mincer, J. (1958) Investment in human capital and personal income income distribution. Journal if Political Economy, LXVI, 281-302.

Social Indicators (2002), House of Commons, Research Report 02/01

Sloane, P.J. (2003) Much ado about nothing: What does the over-education literature really tell us? In Over-education in Europe: Current issues in theory and policy, Büchel, F., de Grip, A. and Mertens, A. (eds), Edward Elgar

Thurow, L. (1975) Generating Inequality: Mechanisms of Distributions in the US Economy, Basic Books

Verdugo, R. and Verdugo, N. (1989) The Impact of Surplus Schooling on Earnings: Some Additional Findings. Journal of Human Resources, 24, 629-643.

Walker, I. and Zhu, Y. (2005) The college wage premium, over-education and the expansion of higher education in the UK, 'Institute for the Study of Labor (IZA), Bonn' Discussion Paper number 1627 (downloadable from http://www.iza.org/). .

Wolf, A. (2002) Does Education Matter? Myths about education and economic growth. London: Penguin Press 
Figure 1: Participation to higher education in Britain (1979-2000)

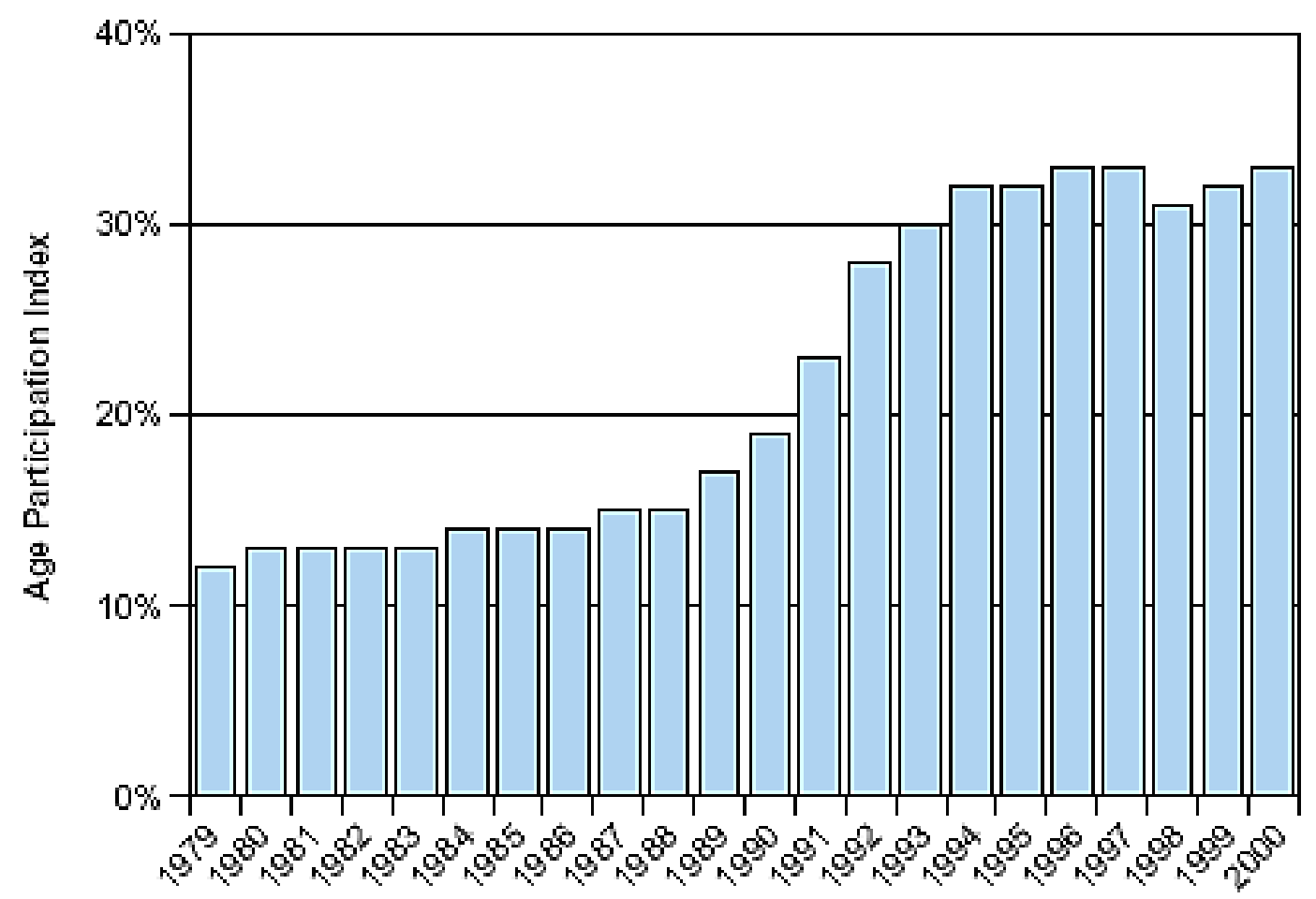

Source: Social Indicators (2002) 
Figure 2: Is your current job appropriate for your education?

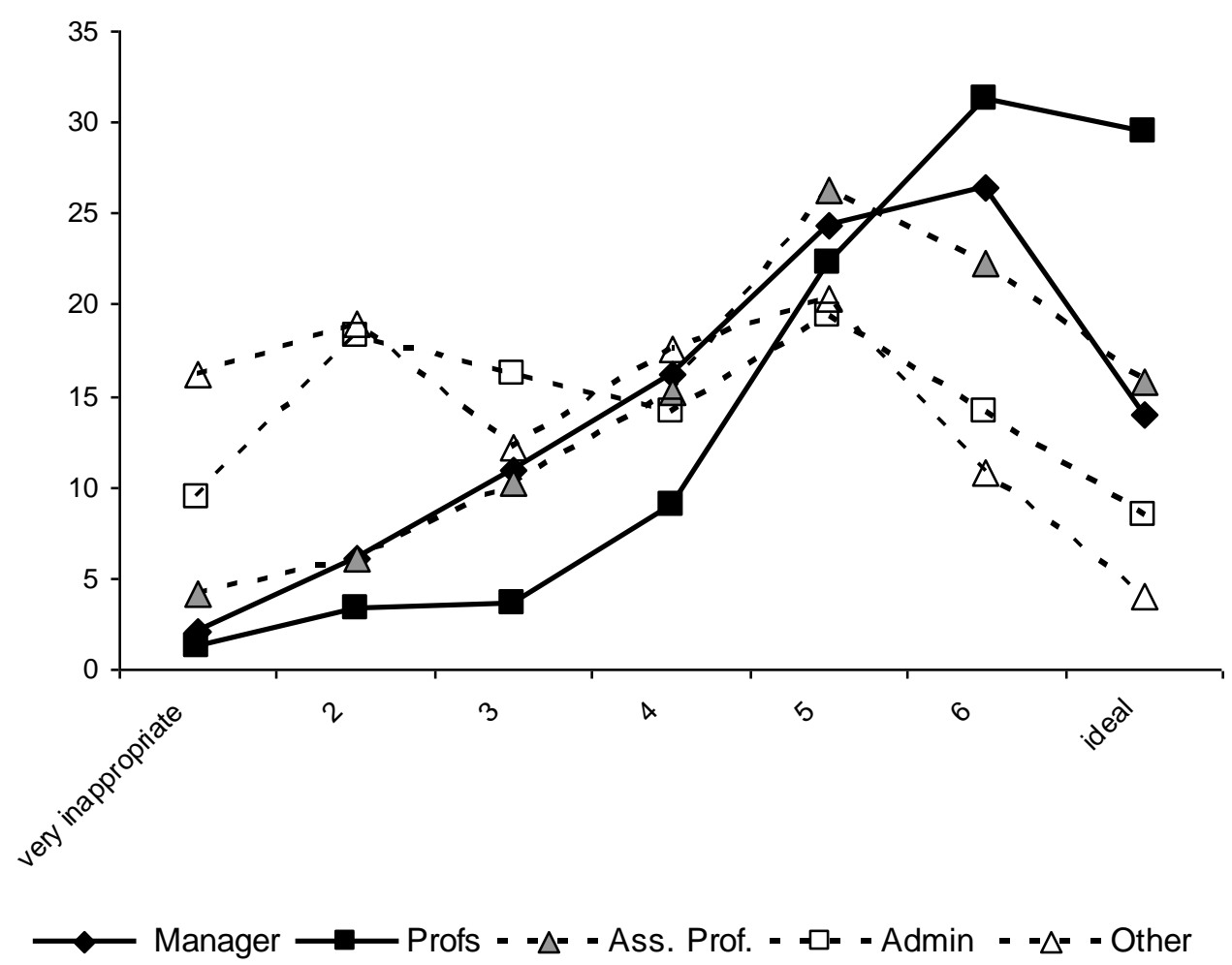

Note: The occupation groups are defined using the one digit classification of the Standard Occupation Code 2000. Manager includes Managers and Administrators. Profs is for Professional Occupations. Ass. Prof, represents Associate Professionals and Technical Occupations. Admin defines Clerical and Secretarial Occupation. Other includes all remaining occupation groups. 
Figure 3: Distribution of unobservable characteristics by over-education group

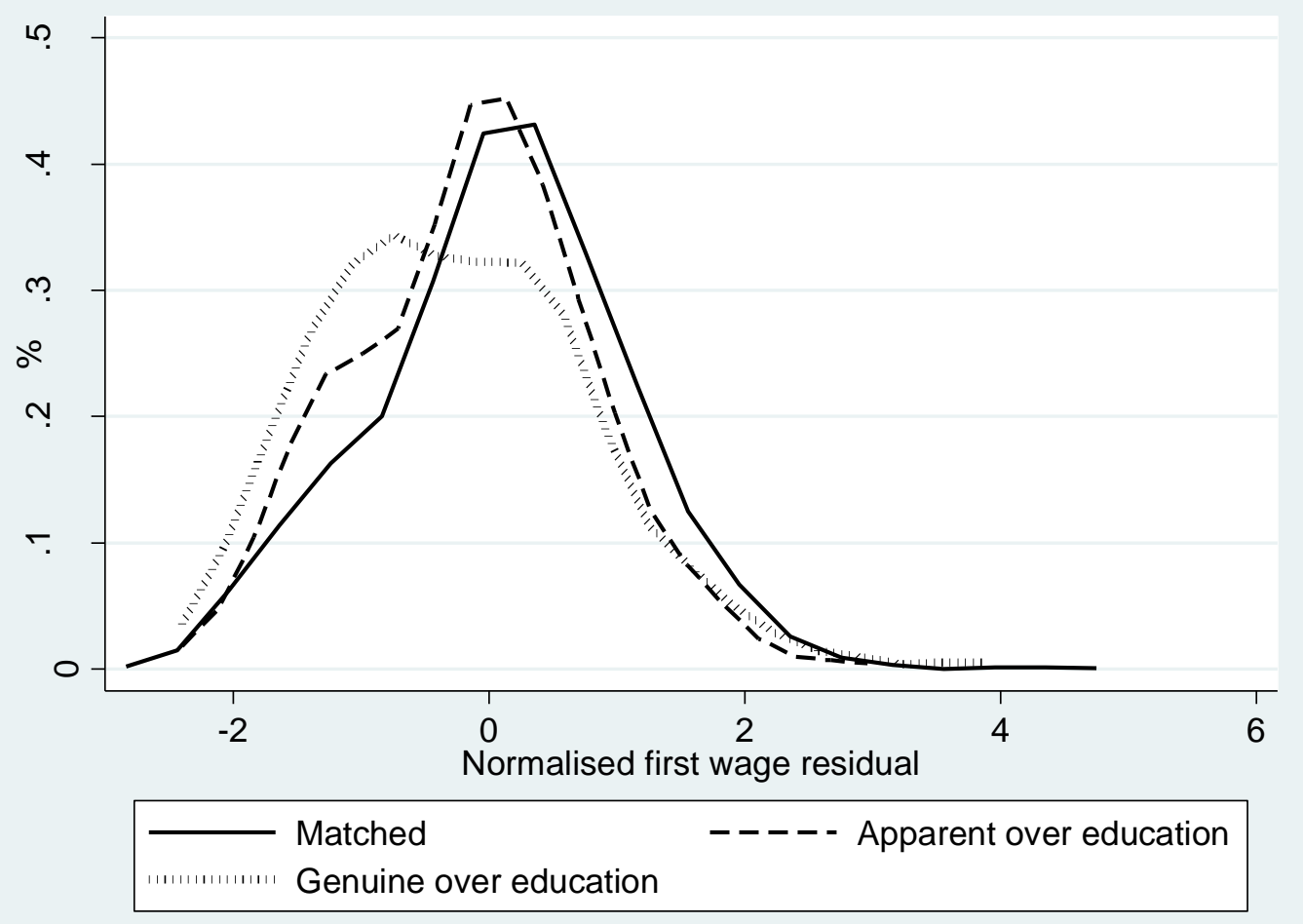

Note: the distributions of hourly wage residuals were smoothed using Epanechnikov kernel function (see Appendix 2). 
Figure 4: Hourly wage distribution by over-education group

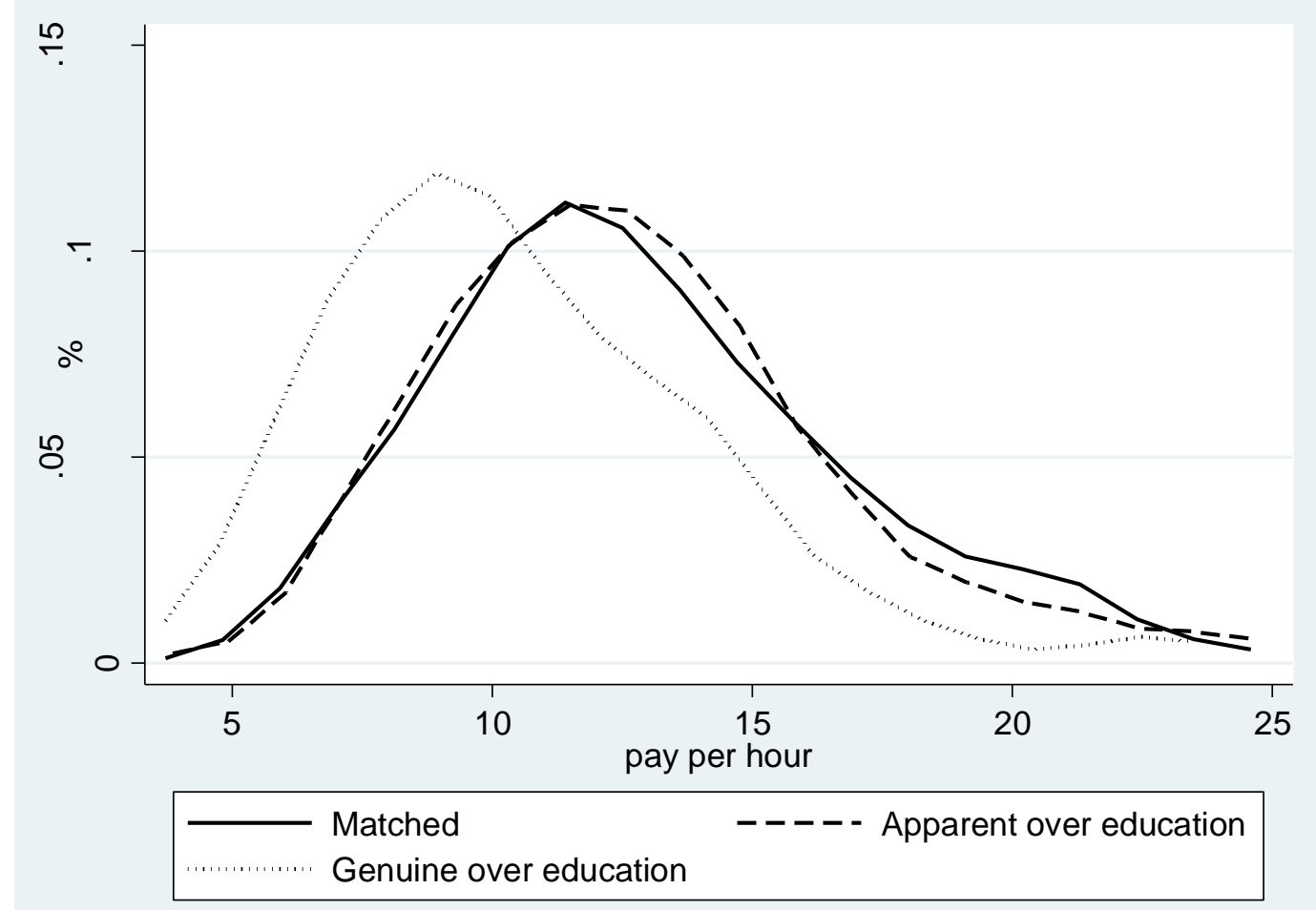

Note: the distributions of hourly wage were smoothed using Epanechnikov kernel function (see Appendix 2). 


\begin{tabular}{|c|c|c|c|c|}
\hline & \multicolumn{4}{|c|}{ Over-education } \\
\hline & Matched & Apparent & Genuine & All Groups \\
\hline Number of Observations & 1,624 & 489 & 371 & 2,484 \\
\hline \multicolumn{5}{|l|}{ A - Reasons for choosing job in \% } \\
\hline Exactly job wanted & 60.7 & 59.5 & $30.2 * *$ & 55.9 \\
\hline Salary level & 46.7 & 49.7 & $38.8 * *$ & 46.1 \\
\hline Other job conditions & 37.1 & 39.3 & 33.4 & 37.0 \\
\hline Location & 55.9 & 54.2 & 52.3 & 55.0 \\
\hline Employer of choice & 25.9 & $32.3 * *$ & 26.2 & 27.2 \\
\hline Interesting work & 58.4 & $62.8^{*}$ & $49.6 * *$ & 57.9 \\
\hline Career development & 61.0 & $66.7 * *$ & $46.9 * *$ & 60.0 \\
\hline Job security & 36.1 & 38.6 & 37.7 & 36.8 \\
\hline Partner's career & 9.0 & $5.9 * *$ & 9.4 & 8.4 \\
\hline Suits in short run & 10.3 & 11.7 & $24.5^{* *}$ & 12.7 \\
\hline Better than unemployment & 7.3 & 6.1 & $21.3 * *$ & 9.2 \\
\hline Other factors & 1.8 & 2.7 & $3.8^{* *}$ & 2.2 \\
\hline \multicolumn{5}{|l|}{ B - How long to learn job? } \\
\hline Missing & 0.9 & 0.2 & 0.3 & 0.7 \\
\hline Less than 1 week & 3.4 & 4.1 & 5.7 & 3.9 \\
\hline Less than 1 month & 11.6 & 8.8 & 15.4 & 11.6 \\
\hline Between 1-3 months & 22.3 & 27.8 & 32.6 & 24.9 \\
\hline Between 3-6 months & 21.4 & 27.8 & 21.3 & 22.7 \\
\hline Between 6-12 months & 19.1 & 15.1 & 13.2 & 17.5 \\
\hline Between 1-2 years & 12.4 & 9.4 & 9.2 & 11.3 \\
\hline More than 2 years & 8.7 & 6.8 & 2.4 & 7.4 \\
\hline Average time to learn in weeks & $\begin{array}{c}33.3 \\
(39.5)\end{array}$ & $\begin{array}{l}28.0 * \\
(35.9)\end{array}$ & $\begin{array}{l}21.0^{*} \\
(28.4)\end{array}$ & $\begin{array}{c}30.4 \\
(37.6)\end{array}$ \\
\hline \multicolumn{5}{|c|}{ C: Satisfied with career development so far } \\
\hline Very satisfied & 33.2 & 32.3 & 10.8 & 29.7 \\
\hline Reasonably satisfied & 58.7 & 61.3 & 54.2 & 58.6 \\
\hline Not very satisfied & 6.7 & 5.9 & 24.8 & 9.3 \\
\hline Dissatisfied & 1.0 & 0.1 & 9.7 & 2.2 \\
\hline Missing & 0.2 & 0.0 & 0.5 & 0.2 \\
\hline \multicolumn{5}{|l|}{ D: Job satisfaction } \\
\hline Missing & 0.6 & 0.2 & 0.3 & 0.4 \\
\hline Not satisfied 1 & 1.0 & 0.6 & 4.8 & 1.5 \\
\hline 2 & 2.3 & 2.0 & 7.0 & 3.0 \\
\hline 3 & 6.3 & 4.1 & 14.0 & 7.0 \\
\hline 4 & 14.4 & 13.9 & 18.6 & 14.9 \\
\hline 5 & 40.2 & 36.8 & 32.9 & 38.5 \\
\hline 6 & 31.5 & 35.4 & 18.6 & 30.3 \\
\hline Completely satisfied & 3.6 & 6.9 & 3.8 & 4.3 \\
\hline \multicolumn{5}{|c|}{$\begin{array}{l}\text { Note: ** and * denote that constructed confidence intervals at } 95 \% \text { and } 99 \% \text { for the difference between the } \\
\text { percentage or mean and the corresponding one for the matched group in column } 1 \text { excludes the no difference } \\
\text { value of zero. Figures in parentheses are standard deviations and all other figures are percentages over the } \\
\text { response categories. For a given group for Panel A the sum of percentages across reasons is greater than } 100 \% \\
\text { as several reasons could be given. }\end{array}$} \\
\hline
\end{tabular}


Table 2: Comparing measures of over-education

\begin{tabular}{|l|c|c|c|c|}
\hline \multirow{2}{*}{$\begin{array}{l}\text { Alternative definition of Over- } \\
\text { Education }\end{array}$} & \multicolumn{3}{|l|}{} \\
\cline { 2 - 5 } & Matched & Apparent & Genuine & All Groups \\
\hline \hline $\begin{array}{l}\text { Panel A: } \\
\text { Respondent reported degree } \\
\text { was a stated requirement for } \\
\text { getting current job? }\end{array}$ & $81.7 \%$ & $76.1 \%$ & $27.9 \%$ & $72.7 \%$ \\
\hline $\begin{array}{l}\text { Total Number of observations } \\
\text { after omitting missing answers or } \\
\text { don't know }\end{array}$ & 1564 & 464 & 348 & \\
\hline & & & & \\
\hline $\begin{array}{l}\text { Panel B: } \\
\text { In a job where less than 30\% of } \\
\text { workers have a degree? }\end{array}$ & $14.0 \%$ & $39.1 \%$ & $67.1 \%$ & $26.9 \%$ \\
\hline Total number of cases & 1,624 & 489 & 371 & 2,484 \\
\hline & & & & \\
\hline $\begin{array}{l}\text { Panel C: } \\
\text { Elias and Purcell definition of } \\
\text { graduate occupation }\end{array}$ & & & & \\
\hline Traditional & & & & \\
\hline Modern & $36.0 \%$ & $2.0 \%$ & $0.5 \%$ & $24.0 \%$ \\
\hline New & $29.5 \%$ & $9.8 \%$ & $4.8 \%$ & $21.9 \%$ \\
\hline Niche & $17.7 \%$ & $32.3 \%$ & $16.2 \%$ & $20.4 \%$ \\
\hline Non-graduate & $15.5 \%$ & $34.6 \%$ & $36.7 \%$ & $22.4 \%$ \\
\hline Total number of cases & $1.3 \%$ & $21.3 \%$ & $41.8 \%$ & $11.3 \%$ \\
\hline & 1,624 & 489 & 371 & 2,484 \\
\hline
\end{tabular}

Note: For each panel the figures are percentages over the response categories. 
Table 3: Percentage reporting that the skill was developed on 1995 degree course and over-skilling by over-education group.

\begin{tabular}{|c|c|c|c|c|}
\hline In percentage & Matched & Apparent & Genuine & Total \\
\hline \multicolumn{5}{|l|}{$\begin{array}{l}\text { Skills Developed at } \\
\text { university }\end{array}$} \\
\hline Problem Solving & 86.3 & $82.6 * *$ & $79.5 * *$ & 84.5 \\
\hline Written Communication & 92.9 & $95.9 * *$ & $95.7 *$ & 93.9 \\
\hline Spoken Communication & 86.2 & 88.3 & 85.2 & 86.4 \\
\hline Foreign Language & 18.3 & 19.0 & 19.9 & 18.7 \\
\hline Numeracy & 71.1 & $66.9 *$ & $60.6^{* *}$ & 68.7 \\
\hline Basic computer & 76.1 & 76.9 & $71.7^{*}$ & 75.6 \\
\hline Advanced IT & 34.3 & $30.1 *$ & $23.5^{* *}$ & 31.8 \\
\hline Research & 94.0 & 92.6 & 94.3 & 93.8 \\
\hline Creativity & 74.4 & 76.5 & 76.3 & 75.1 \\
\hline Entrepreneurial & 51.2 & 50.3 & $39.9 * *$ & 49.3 \\
\hline Teamwork & 98.9 & 98.8 & $97.8^{*}$ & 98.8 \\
\hline Management & 91.2 & 90.6 & $75.2 * *$ & 88.7 \\
\hline Leadership & 91.9 & 91.0 & $74.4 * *$ & 89.1 \\
\hline \multicolumn{5}{|l|}{ Overskilling $^{\mathbf{A}}$} \\
\hline Problem Solving & 0.7 & 0.6 & $3.8 * *$ & 1.1 \\
\hline Written Communication & 0.7 & 0.6 & $8.1 * *$ & 1.8 \\
\hline Spoken Communication & 0.2 & 0.0 & 0.5 & 0.2 \\
\hline Foreign Language & 10.3 & $13.3^{*}$ & $15.1 * *$ & 11.6 \\
\hline Numeracy & 1.8 & 2.9 & $7.3^{* *}$ & 2.9 \\
\hline Basic computer & 0.4 & $2.5^{* *}$ & $3.5^{* *}$ & 1.2 \\
\hline Advanced IT & 4.3 & 3.9 & 4.6 & 4.3 \\
\hline Research & 12.4 & 12.9 & $29.1 * *$ & 15.0 \\
\hline Creativity & 3.4 & 4.3 & $17.3 * *$ & 5.6 \\
\hline Observations & 1,624 & 489 & 371 & 2,484 \\
\hline
\end{tabular}

Note: $* *$ and $*$ denote that constructed confidence intervals at $95 \%$ and $99 \%$ for the difference between the percentage and the corresponding one for the matched group in column 1 excludes the no difference value of zero.

${ }^{\text {A }}$ Overskilling is equal to one if the individual reports having developed the given skill at university and does not use it in his/her current job and zero otherwise. Note that no cases of overskilling were found for enterpreneurship, teamwork, management and leadership 
Table 4: Multinomial logit models for determinants of overeducation.-marginal effects on probabilities estimated at the mean of explanatory variables

\begin{tabular}{|c|c|c|c|c|c|c|c|c|}
\hline \multirow{2}{*}{$\begin{array}{l}\text { Definition } \\
\text { Category }\end{array}$} & \multicolumn{2}{|c|}{ (1) Satisfaction } & \multirow{2}{*}{$\begin{array}{c}(2) \\
<30 \% \\
\text { graduate in } \\
\text { occupation. }\end{array}$} & \multirow{2}{*}{$\begin{array}{c}(3) \\
\text { Degree } \\
\text { not } \\
\text { Required }\end{array}$} & \multicolumn{4}{|c|}{ (4) Elias and Purcell } \\
\hline & $\begin{array}{c}\text { App. } \\
\text { over } \\
\text { education } \\
\end{array}$ & $\begin{array}{c}\text { Gen. } \\
\text { Over } \\
\text { education }\end{array}$ & & & Modern & New & Niche & $\begin{array}{l}\text { Non- } \\
\text { grad }\end{array}$ \\
\hline Male & $\begin{array}{l}-0.017 \\
(0.018)\end{array}$ & $\begin{array}{l}-0.010 \\
(0.014)\end{array}$ & $\begin{array}{l}0.013 \\
(0.019)\end{array}$ & $\begin{array}{l}0.037 \\
(0.020)\end{array}$ & $\begin{array}{l}0.001 \\
(0.021)\end{array}$ & $\begin{array}{l}-0.001 \\
(0.019)\end{array}$ & $\begin{array}{l}0.015 \\
(0.022)\end{array}$ & $\begin{array}{l}-0.005 \\
(0.012)\end{array}$ \\
\hline Age & $\begin{array}{l}-0.006 \\
(0.007)\end{array}$ & $\begin{array}{l}-0.010 \\
(0.006)\end{array}$ & $\begin{array}{l}-0.009 \\
(0.008)\end{array}$ & $\begin{array}{l}-0.002 \\
(0.008)\end{array}$ & $\begin{array}{l}\mathbf{0 . 0 2 0} \\
(0.008)\end{array}$ & $\begin{array}{l}-\mathbf{- 0 . 0 1 3} \\
(0.007)\end{array}$ & $\begin{array}{l}-0.007 \\
(0.008)\end{array}$ & $\begin{array}{l}-0.006 \\
(0.005)\end{array}$ \\
\hline A-level score & $\begin{array}{l}0.001 \\
(0.001)\end{array}$ & $\begin{array}{l}-0.002 \\
(0.001)\end{array}$ & $\begin{array}{l}\mathbf{- 0 . 0 0 5} \\
(0.002)\end{array}$ & $\begin{array}{l}-0.002 \\
(0.002)\end{array}$ & $\begin{array}{l}0.002 \\
(0.002)\end{array}$ & $\begin{array}{l}0.001 \\
(0.002)\end{array}$ & $\begin{array}{l}\mathbf{- 0 . 0 0 5} \\
(0.002)\end{array}$ & $\begin{array}{l}0.000 \\
(0.001)\end{array}$ \\
\hline \multicolumn{9}{|c|}{ Type of higher education institution (Reference Old University) } \\
\hline $\begin{array}{l}\text { 1960’s estabished } \\
\text { Universities }\end{array}$ & $\begin{array}{l}-0.046 \\
(0.036)\end{array}$ & $\begin{array}{l}0.031 \\
(0.025)\end{array}$ & $\begin{array}{l}0.006 \\
(0.036)\end{array}$ & $\begin{array}{l}-0.049 \\
(0.038)\end{array}$ & $\begin{array}{l}0.002 \\
(0.036)\end{array}$ & $\begin{array}{l}\mathbf{0 . 0 7 0} \\
(0.036)\end{array}$ & $\begin{array}{l}0.010 \\
(0.039)\end{array}$ & $\begin{array}{l}-0.024 \\
(0.024)\end{array}$ \\
\hline $\begin{array}{c}\text { New (post 1992) } \\
\text { Universities }\end{array}$ & $\begin{array}{l}\mathbf{0 . 0 5 0} \\
(0.024)\end{array}$ & $\begin{array}{l}0.009 \\
(0.019)\end{array}$ & $\begin{array}{l}0.017 \\
(0.027)\end{array}$ & $\begin{array}{l}0.069 \\
(0.028)\end{array}$ & $\begin{array}{l}-0.010 \\
(0.030)\end{array}$ & $\begin{array}{l}\mathbf{0 . 0 8 5} \\
(0.027)\end{array}$ & $\begin{array}{l}0.017 \\
(0.030)\end{array}$ & $\begin{array}{l}0.010 \\
(0.017)\end{array}$ \\
\hline HE Colleges & $\begin{array}{l}0.065 \\
(0.039)\end{array}$ & $\begin{array}{l}0.046 \\
(0.029)\end{array}$ & $\begin{array}{l}0.024 \\
(0.043)\end{array}$ & $\begin{array}{l}\mathbf{0 . 0 8 4} \\
(0.042)\end{array}$ & $\begin{array}{l}-0.005 \\
(0.041)\end{array}$ & $\begin{array}{l}0.007 \\
(0.045)\end{array}$ & $\begin{array}{l}-0.016 \\
(0.049)\end{array}$ & $\begin{array}{l}0.027 \\
(0.027)\end{array}$ \\
\hline \multicolumn{9}{|c|}{ Degree Classification (Reference III class, pass or ordinary) } \\
\hline First & $\begin{array}{l}-0.048 \\
(0.039)\end{array}$ & $\begin{array}{l}-0.028 \\
(0.030)\end{array}$ & $\begin{array}{l}-0.076 \\
(0.041)\end{array}$ & $\begin{array}{l}\mathbf{- 0 . 2 1 4} \\
(0.048)\end{array}$ & $\begin{array}{l}0.004 \\
(0.041)\end{array}$ & $\begin{array}{l}\mathbf{0 . 1 1 2} \\
(0.041)\end{array}$ & $\begin{array}{l}-0.069 \\
(0.047)\end{array}$ & $\begin{array}{l}\mathbf{- 0 . 0 6 8} \\
(0.026)\end{array}$ \\
\hline II-1 & $\begin{array}{l}-0.003 \\
(0.027)\end{array}$ & $\begin{array}{l}-0.028 \\
(0.022)\end{array}$ & $\begin{array}{l}-0.055 \\
(0.030)\end{array}$ & $\begin{array}{l}\mathbf{- 0 . 0 7 3} \\
(0.030)\end{array}$ & $\begin{array}{l}0.034 \\
(0.031)\end{array}$ & $\begin{array}{l}\mathbf{0 . 0 8 2} \\
(0.032)\end{array}$ & $\begin{array}{l}-0.026 \\
(0.033)\end{array}$ & $\begin{array}{l}\mathbf{- 0 . 0 6 6} \\
(0.019)\end{array}$ \\
\hline II-2 & $\begin{array}{l}-0.004 \\
(0.029)\end{array}$ & $\begin{array}{l}-0.027 \\
(0.022)\end{array}$ & $\begin{array}{l}-0.042 \\
(0.031)\end{array}$ & $\begin{array}{l}0.001 \\
(0.032)\end{array}$ & $\begin{array}{l}0.054 \\
(0.033)\end{array}$ & $\begin{array}{l}\mathbf{0 . 0 9 4} \\
(0.034)\end{array}$ & $\begin{array}{l}0.002 \\
(0.034)\end{array}$ & $\begin{array}{l}-\mathbf{- 0 . 0 4 7} \\
(0.019)\end{array}$ \\
\hline \multicolumn{9}{|c|}{ Subject Group (Reference social science) } \\
\hline Humanities & $\begin{array}{l}0.054 \\
(0.049) \\
0.01\end{array}$ & $\begin{array}{l}-0.009 \\
(0.036) \\
0.012\end{array}$ & $\begin{array}{l}-0.057 \\
(0.056) \\
-0.010\end{array}$ & $\begin{array}{l}-0.048 \\
(0.054) \\
-0.043\end{array}$ & $\begin{array}{l}0.020 \\
(0.059) \\
0.019\end{array}$ & $\begin{array}{l}0.000 \\
(0.057) \\
-0.021\end{array}$ & $\begin{array}{l}-0.049 \\
(0.058) \\
-0.074\end{array}$ & $\begin{array}{l}-0.014 \\
(0.037) \\
0.026\end{array}$ \\
\hline Language & $\begin{array}{l}(0.033) \\
-0.061\end{array}$ & $\begin{array}{l}(0.025) \\
0.027\end{array}$ & $\begin{array}{l}(0.036) \\
0.001\end{array}$ & $\begin{array}{l}(0.037) \\
0.005\end{array}$ & $\begin{array}{l}(0.040) \\
-0.077\end{array}$ & $\begin{array}{l}(0.037) \\
0.004\end{array}$ & $\begin{array}{l}(0.040) \\
0.024\end{array}$ & $\begin{array}{l}(0.023) \\
-0.008\end{array}$ \\
\hline Law & $\begin{array}{l}(0.053) \\
-0.145\end{array}$ & $\begin{array}{l}(0.035) \\
-0.030\end{array}$ & $\begin{array}{l}(0.054) \\
-0.127\end{array}$ & $\begin{array}{l}(0.052) \\
-0.172\end{array}$ & $\begin{array}{l}(0.065) \\
-0.125\end{array}$ & $\begin{array}{l}(0.052) \\
-0.202\end{array}$ & $\begin{array}{l}(0.056) \\
-0.005\end{array}$ & $\begin{array}{l}(0.037) \\
-0.053\end{array}$ \\
\hline Math Computing & $\begin{array}{l}(0.058) \\
0.012\end{array}$ & $\begin{array}{l}(0.038) \\
-0.172\end{array}$ & $\begin{array}{l}(0.059) \\
-0.123\end{array}$ & $\begin{array}{l}(0.059) \\
-0.102\end{array}$ & $\begin{array}{l}(0.074) \\
0.264\end{array}$ & $\begin{array}{l}(0.074) \\
-0.162\end{array}$ & $\begin{array}{l}(0.063) \\
-0.033\end{array}$ & $\begin{array}{l}(0.046) \\
-0.039\end{array}$ \\
\hline Natural Science & $\begin{array}{l}(0.040) \\
-0.048\end{array}$ & $\begin{array}{l}(0.042) \\
-0.005\end{array}$ & $\begin{array}{l}(0.047) \\
-0.068\end{array}$ & $\begin{array}{l}(0.047) \\
-0.112\end{array}$ & $\begin{array}{l}(0.041) \\
-0.033\end{array}$ & $\begin{array}{l}(0.053) \\
0.050\end{array}$ & $\begin{array}{l}(0.049) \\
-0.096\end{array}$ & $\begin{array}{l}(0.031) \\
-0.048\end{array}$ \\
\hline Medicine and related & $\begin{array}{l}(0.032) \\
\mathbf{0 . 1 2 9}\end{array}$ & $\begin{array}{l}(0.023) \\
-0.128\end{array}$ & $\begin{array}{l}(0.035) \\
-0.135\end{array}$ & $\begin{array}{l}(0.035) \\
-0.213\end{array}$ & $\begin{array}{l}(0.037) \\
-0.106\end{array}$ & $\begin{array}{l}(0.033) \\
\mathbf{0 . 1 4 4}\end{array}$ & $\begin{array}{l}(0.038) \\
-0.125\end{array}$ & $\begin{array}{l}(0.022) \\
-0.115\end{array}$ \\
\hline Engineering & $\begin{array}{l}(0.034) \\
-0.043\end{array}$ & $\begin{array}{l}(0.042) \\
-0.108\end{array}$ & $\begin{array}{l}(0.046) \\
0.010\end{array}$ & $\begin{array}{l}(0.050) \\
-0.045\end{array}$ & $\begin{array}{l}(0.053) \\
\mathbf{0 . 1 7 3}\end{array}$ & $\begin{array}{l}(0.040) \\
0.103\end{array}$ & $\begin{array}{l}(0.051) \\
-0.017\end{array}$ & $\begin{array}{l}(0.040) \\
-0.024\end{array}$ \\
\hline Business & $\begin{array}{l}(0.040) \\
0.095\end{array}$ & $\begin{array}{l}(0.035) \\
-0.01\end{array}$ & $\begin{array}{l}(0.041) \\
\mathbf{0 . 0 7 4}\end{array}$ & $\begin{array}{l}(0.043) \\
0.064\end{array}$ & $\begin{array}{l}(0.041) \\
-0.120\end{array}$ & $\begin{array}{l}(0.041) \\
0.122\end{array}$ & $\begin{array}{l}(0.046) \\
0.064\end{array}$ & $\begin{array}{l}(0.028) \\
0.065\end{array}$ \\
\hline Education & $\begin{array}{l}(0.031) \\
-0.286\end{array}$ & $\begin{array}{l}(0.024) \\
-0.096\end{array}$ & $\begin{array}{l}(0.034) \\
-0.338\end{array}$ & $\begin{array}{l}(0.036) \\
-0.289\end{array}$ & $\begin{array}{l}(0.050) \\
0.356\end{array}$ & $\begin{array}{l}(0.036) \\
-0.125\end{array}$ & $\begin{array}{l}(0.040) \\
-0.250\end{array}$ & $\begin{array}{l}(0.022) \\
-0.116\end{array}$ \\
\hline Other vocational & $\begin{array}{l}(0.060) \\
-0.017\end{array}$ & $\begin{array}{l}(0.032) \\
-0.091\end{array}$ & $\begin{array}{l}(0.056) \\
-0.042\end{array}$ & $\begin{array}{l}(0.048) \\
-0.088\end{array}$ & $\begin{array}{l}(0.042) \\
-0.146\end{array}$ & $\begin{array}{l}(0.059) \\
\mathbf{0 . 1 3 9}\end{array}$ & $\begin{array}{l}(0.061) \\
-0.036\end{array}$ & $\begin{array}{l}(0.041) \\
-0.047\end{array}$ \\
\hline Interdisciplinary & $\begin{array}{l}(0.042) \\
0.003 \\
(0.043)\end{array}$ & $\begin{array}{l}(0.035) \\
0.016 \\
(0.031)\end{array}$ & $\begin{array}{l}(0.046) \\
-0.006 \\
(0.048)\end{array}$ & $\begin{array}{l}(0.047) \\
0.054 \\
(0.047)\end{array}$ & $\begin{array}{l}(0.062) \\
-0.005 \\
(0.054)\end{array}$ & $\begin{array}{l}(0.043) \\
-0.037 \\
(0.050)\end{array}$ & $\begin{array}{l}(0.051) \\
-0.041 \\
(0.053)\end{array}$ & $\begin{array}{l}(0.031) \\
0.02 \\
(0.029)\end{array}$ \\
\hline
\end{tabular}

Continued on next page... 
Table 4 continued

\begin{tabular}{|c|c|c|c|c|c|c|c|c|}
\hline Definition & \multicolumn{2}{|c|}{ (1) Satisfaction } & $(2)$ & (3) & \multicolumn{4}{|c|}{ (4) Elias and Purcell } \\
\hline \multicolumn{9}{|c|}{ Additional qualification (Reference None) } \\
\hline $\mathrm{PhD}$ & $\begin{array}{l}-0.082 \\
(0.060)\end{array}$ & $\begin{array}{l}-0.098 \\
(0.051)\end{array}$ & $\begin{array}{l}\mathbf{- 0 . 1 7 4} \\
(0.075)\end{array}$ & $\begin{array}{l}\mathbf{- 0 . 2 3 7} \\
(0.095)\end{array}$ & $\begin{array}{l}-0.001 \\
(0.072)\end{array}$ & $\begin{array}{l}-0.145 \\
(0.081)\end{array}$ & $\begin{array}{l}-0.080 \\
(0.087)\end{array}$ & $\begin{array}{l}-0.095 \\
(0.066)\end{array}$ \\
\hline Other post-grad. studies & $\begin{array}{l}-0.035 \\
(0.021)\end{array}$ & $\begin{array}{l}\mathbf{- 0 . 0 8 5} \\
(0.019)\end{array}$ & $\begin{array}{l}\mathbf{- 0 . 0 7 7} \\
(0.024)\end{array}$ & $\begin{array}{l}\mathbf{- 0 . 1 3 2} \\
(0.025)\end{array}$ & $\begin{array}{l}\mathbf{0 . 0 6 3} \\
(0.023)\end{array}$ & $\begin{array}{l}\mathbf{- 0 . 0 5 2} \\
(0.023)\end{array}$ & $\begin{array}{l}\mathbf{- 0 . 0 5 7} \\
(0.026)\end{array}$ & $\begin{array}{l}\mathbf{- 0 . 0 5 4} \\
(0.017)\end{array}$ \\
\hline Professional qualification & $\begin{array}{l}0.035 \\
(0.020)\end{array}$ & $\begin{array}{l}0.001 \\
(0.017)\end{array}$ & $\begin{array}{l}0.002 \\
(0.023)\end{array}$ & $\begin{array}{l}-0.000 \\
(0.024)\end{array}$ & $\begin{array}{l}\mathbf{- 0 . 1 0 6} \\
(0.028)\end{array}$ & $\begin{array}{l}\mathbf{0 . 0 5 3} \\
(0.022)\end{array}$ & $\begin{array}{l}\mathbf{0 . 0 5 6} \\
(0.025)\end{array}$ & $\begin{array}{l}0.019 \\
(0.015)\end{array}$ \\
\hline Parents - not employed & $\begin{array}{l}0.017 \\
(0.066)\end{array}$ & $\begin{array}{l}\mathbf{0 . 0 8 5} \\
(0.041)\end{array}$ & $\begin{array}{l}0.066 \\
(0.066)\end{array}$ & $\begin{array}{l}0.052 \\
(0.068)\end{array}$ & $\begin{array}{l}-0.056 \\
(0.072)\end{array}$ & $\begin{array}{l}0.024 \\
(0.068)\end{array}$ & $\begin{array}{l}0.039 \\
(0.075)\end{array}$ & $\begin{array}{l}0.034 \\
(0.043)\end{array}$ \\
\hline \multicolumn{9}{|c|}{ Skills stated as having been acquired on degree course } \\
\hline Problem Solving Skills & $\begin{array}{l}-0.034 \\
(0.023)\end{array}$ & $\begin{array}{l}-0.023 \\
(0.017)\end{array}$ & $\begin{array}{l}0.013 \\
(0.027)\end{array}$ & $\begin{array}{l}-0.013 \\
(0.025)\end{array}$ & $\begin{array}{l}-0.019 \\
(0.027)\end{array}$ & $\begin{array}{l}-0.030 \\
(0.025)\end{array}$ & $\begin{array}{l}-0.006 \\
(0.028)\end{array}$ & $\begin{array}{l}-0.000 \\
(0.017)\end{array}$ \\
\hline Written Com Skills & $\begin{array}{l}\mathbf{0 . 0 8 9} \\
(0.041)\end{array}$ & $\begin{array}{l}0.029 \\
(0.032)\end{array}$ & $\begin{array}{l}0.021 \\
(0.041)\end{array}$ & $\begin{array}{l}0.049 \\
(0.042)\end{array}$ & $\begin{array}{l}0.016 \\
(0.041)\end{array}$ & $\begin{array}{l}0.086 \\
(0.044)\end{array}$ & $\begin{array}{l}-0.031 \\
(0.044)\end{array}$ & $\begin{array}{l}0.036 \\
(0.031)\end{array}$ \\
\hline Spoken Com Skills & $\begin{array}{l}0.013 \\
(0.026)\end{array}$ & $\begin{array}{l}-0.026 \\
(0.020)\end{array}$ & $\begin{array}{l}-0.052 \\
(0.027)\end{array}$ & $\begin{array}{l}-0.054 \\
(0.029)\end{array}$ & $\begin{array}{l}0.019 \\
(0.032)\end{array}$ & $\begin{array}{l}0.004 \\
(0.028)\end{array}$ & $\begin{array}{l}0.019 \\
(0.031)\end{array}$ & $\begin{array}{l}-0.031 \\
(0.017)\end{array}$ \\
\hline Foreign Lang Skills & $\begin{array}{l}-0.007 \\
(0.024)\end{array}$ & $\begin{array}{l}-0.004 \\
(0.019)\end{array}$ & $\begin{array}{l}-0.005 \\
(0.026)\end{array}$ & $\begin{array}{l}-0.039 \\
(0.027)\end{array}$ & $\begin{array}{l}-0.045 \\
(0.027)\end{array}$ & $\begin{array}{l}0.029 \\
(0.024)\end{array}$ & $\begin{array}{l}-0.010 \\
(0.028)\end{array}$ & $\begin{array}{l}-0.009 \\
(0.018)\end{array}$ \\
\hline Numeracy Skills & $\begin{array}{l}-0.012 \\
(0.024)\end{array}$ & $\begin{array}{l}-0.009 \\
(0.018)\end{array}$ & $\begin{array}{l}-0.047 \\
(0.026)\end{array}$ & $\begin{array}{l}-0.048 \\
(0.027)\end{array}$ & $\begin{array}{l}-0.032 \\
(0.029)\end{array}$ & $\begin{array}{l}0.008 \\
(0.026)\end{array}$ & $\begin{array}{l}-0.032 \\
(0.027)\end{array}$ & $\begin{array}{l}0.003 \\
(0.018)\end{array}$ \\
\hline Basic computer Skills & $\begin{array}{l}0.037 \\
(0.022)\end{array}$ & $\begin{array}{l}-0.005 \\
(0.016)\end{array}$ & $\begin{array}{l}0.018 \\
(0.024)\end{array}$ & $\begin{array}{l}-0.010 \\
(0.024)\end{array}$ & $\begin{array}{l}-0.026 \\
(0.025)\end{array}$ & $\begin{array}{l}0.031 \\
(0.023)\end{array}$ & $\begin{array}{l}0.033 \\
(0.026)\end{array}$ & $\begin{array}{l}0.002 \\
(0.016)\end{array}$ \\
\hline Advanced IT Skills & $\begin{array}{l}-0.012 \\
(0.020)\end{array}$ & $\begin{array}{l}-0.012 \\
(0.016)\end{array}$ & $\begin{array}{l}-0.002 \\
(0.022)\end{array}$ & $\begin{array}{l}\mathbf{- 0 . 0 9 0} \\
(0.024)\end{array}$ & $\begin{array}{l}\mathbf{0 . 0 5 3} \\
(0.024)\end{array}$ & $\begin{array}{l}\mathbf{- 0 . 0 5 8} \\
(0.022)\end{array}$ & $\begin{array}{l}\mathbf{- 0 . 0 5 7} \\
(0.025)\end{array}$ & $\begin{array}{l}0.021 \\
(0.014)\end{array}$ \\
\hline Research Skills & $\begin{array}{l}-0.053 \\
(0.033)\end{array}$ & $\begin{array}{l}-0.012 \\
(0.029)\end{array}$ & $\begin{array}{l}0.036 \\
(0.041)\end{array}$ & $\begin{array}{l}0.027 \\
(0.040)\end{array}$ & $\begin{array}{l}-0.010 \\
(0.038)\end{array}$ & $\begin{array}{l}\mathbf{- 0 . 0 7 3} \\
(0.035)\end{array}$ & $\begin{array}{l}-0.018 \\
(0.043)\end{array}$ & $\begin{array}{l}0.021 \\
(0.027)\end{array}$ \\
\hline Creativity Skills & $\begin{array}{l}0.033 \\
(0.020)\end{array}$ & $\begin{array}{l}0.008 \\
(0.017)\end{array}$ & $\begin{array}{l}0.020 \\
(0.023)\end{array}$ & $\begin{array}{l}\mathbf{0 . 0 5 4} \\
(0.024)\end{array}$ & $\begin{array}{l}0.041 \\
(0.024)\end{array}$ & $\begin{array}{l}-0.024 \\
(0.021)\end{array}$ & $\begin{array}{l}0.004 \\
(0.025)\end{array}$ & $\begin{array}{l}0.020 \\
(0.015)\end{array}$ \\
\hline Entrepreneurial Skills & $\begin{array}{l}-0.017 \\
(0.017)\end{array}$ & $\begin{array}{l}-0.024 \\
(0.014)\end{array}$ & $\begin{array}{l}0.024 \\
(0.019)\end{array}$ & $\begin{array}{l}-0.016 \\
(0.019)\end{array}$ & $\begin{array}{l}\mathbf{- 0 . 0 5 1} \\
(0.019)\end{array}$ & $\begin{array}{l}\mathbf{0 . 0 6 7} \\
(0.018)\end{array}$ & $\begin{array}{l}\mathbf{0 . 0 8 1} \\
(0.020)\end{array}$ & $\begin{array}{l}\mathbf{- 0 . 0 4 1} \\
(0.012)\end{array}$ \\
\hline Teamwork Skills & $\begin{array}{l}-0.047 \\
(0.076)\end{array}$ & $\begin{array}{l}0.012 \\
(0.051)\end{array}$ & $\begin{array}{l}0.027 \\
(0.079)\end{array}$ & $\begin{array}{l}-0.005 \\
(0.093)\end{array}$ & $\begin{array}{l}-0.115 \\
(0.082)\end{array}$ & $\begin{array}{l}0.033 \\
(0.107)\end{array}$ & $\begin{array}{l}-0.049 \\
(0.097)\end{array}$ & $\begin{array}{l}0.034 \\
(0.050)\end{array}$ \\
\hline Management Skills & $\begin{array}{l}0.002 \\
(0.033)\end{array}$ & $\begin{array}{l}\mathbf{- 0 . 0 5 7} \\
(0.022)\end{array}$ & $\begin{array}{l}\mathbf{- 0 . 0 6 7} \\
(0.034)\end{array}$ & $\begin{array}{l}\mathbf{- 0 . 1 1 9} \\
(0.034)\end{array}$ & $\begin{array}{l}-0.006 \\
(0.038)\end{array}$ & $\begin{array}{l}0.027 \\
(0.039)\end{array}$ & $\begin{array}{l}-0.029 \\
(0.040)\end{array}$ & $\begin{array}{l}\mathbf{- 0 . 0 5 5} \\
(0.020)\end{array}$ \\
\hline Leadership Skills & $\begin{array}{l}0.004 \\
(0.033)\end{array}$ & $\begin{array}{l}\mathbf{- 0 . 1 0 7} \\
(0.021)\end{array}$ & $\begin{array}{l}\mathbf{- 0 . 0 8 6} \\
(0.034)\end{array}$ & $\begin{array}{l}\mathbf{- 0 . 0 7 6} \\
(0.035)\end{array}$ & $\begin{array}{l}-0.022 \\
(0.038)\end{array}$ & $\begin{array}{l}0.065 \\
(0.037)\end{array}$ & $\begin{array}{l}0.011 \\
(0.039)\end{array}$ & $\begin{array}{l}\mathbf{- 0 . 0 6 1} \\
(0.021)\end{array}$ \\
\hline Unobserved skills & $\begin{array}{l}\mathbf{- 0 . 0 2 9} \\
(0.006)\end{array}$ & $\begin{array}{l}\mathbf{- 0 . 0 3 7} \\
(0.006)\end{array}$ & $\begin{array}{l}\mathbf{- 0 . 0 5 4} \\
(0.009)\end{array}$ & $\begin{array}{l}\mathbf{- 0 . 0 7 9} \\
(0.009)\end{array}$ & $\begin{array}{l}0.025 \\
(0.020)\end{array}$ & $\begin{array}{l}\mathbf{- 0 . 0 0 6} \\
(0.002)\end{array}$ & $\begin{array}{l}\mathbf{- 0 . 0 3 2} \\
(0.007)\end{array}$ & $\begin{array}{c}\mathbf{- 0 . 0 3 2} \\
(0.005)\end{array}$ \\
\hline
\end{tabular}

Note: The model is estimated on 2484 observations. All marginal effects are estimated at the mean of explanatory variables and the standard errors reported in parentheses are obtained by bootstrap with $\mathrm{k}=500$ replications (see Appendix 2). Bold estimates denote statistical significance at the 5\% level. Additional controls include current region of work, parental social class, school type, missing institution type, indicator for Scottish Higher qualifications and ethnicity. The definitions of overeducation are: (1) Employed in a graduate job for 'matched' workers, not employed in a graduate job and satisfied with their match for 'apparent' and not employed in a graduate job and not satisfied with their match for 'genuine'. (2) Over-educated if in a job with less than $30 \%$ graduates and matched otherwise. (3) Over-educated if a degree was not a requirement for the current job and matched otherwise. (4) Employed in an Elias and Purcell statistical definition of a graduate job. The omitted response category is a 'matched' for specifications (1) to (3) and 'employed in a traditional graduate job' for specification (4). 
Table 5: Multinomial Logit: Determinants of Over-Education for the 1990 and 1995 cohorts.

\begin{tabular}{|c|c|c|c|c|c|c|c|c|}
\hline & \multicolumn{6}{|c|}{1995 Cohort } & \multirow{2}{*}{\multicolumn{2}{|c|}{$\begin{array}{l}\frac{1990 \text { Cohort }}{\text { Post-university }} \\
\text { characteristics and } \\
\text { unobserved skills }\end{array}$}} \\
\hline & \multicolumn{2}{|c|}{$\begin{array}{l}\text { Pre-university } \\
\text { characteristics only }\end{array}$} & \multicolumn{2}{|c|}{$\begin{array}{l}\text { Post-university } \\
\text { characteristics }\end{array}$} & \multicolumn{2}{|c|}{$\begin{array}{l}\text { Post-university } \\
\text { characteristics and } \\
\text { unobserved skills }\end{array}$} & & \\
\hline & $\begin{array}{l}\text { App. } \\
\text { OE }\end{array}$ & Gen. OE & $\begin{array}{l}\text { App. } \\
\text { OE }\end{array}$ & Gen. OE & $\begin{array}{l}\text { App. } \\
\text { OE }\end{array}$ & Gen. OE & $\begin{array}{l}\text { App. } \\
\text { OE }\end{array}$ & Gen. OE \\
\hline $\begin{array}{l}\text { A-level } \\
\text { score }\end{array}$ & $\begin{array}{l}0.000 \\
(0.001)\end{array}$ & $\begin{array}{l}-0.002 \\
(0.001)\end{array}$ & $\begin{array}{l}0.001 \\
(0.001)\end{array}$ & $\begin{array}{l}-0.003 \\
(0.001)\end{array}$ & $\begin{array}{l}0.001 \\
(0.001)\end{array}$ & $\begin{array}{l}-0.003 \\
(0.001)\end{array}$ & $\begin{array}{l}-0.002 \\
(0.001)\end{array}$ & $\begin{array}{l}-0.000 \\
(0.000)\end{array}$ \\
\hline $\begin{array}{l}\text { Scottish } \\
\text { Higher }\end{array}$ & $\begin{array}{l}-0.032 \\
(0.033)\end{array}$ & $\begin{array}{l}0.016 \\
(0.028)\end{array}$ & $\begin{array}{l}-0.013 \\
(0.034)\end{array}$ & $\begin{array}{l}0.024 \\
(0.028)\end{array}$ & $\begin{array}{l}-0.038 \\
(0.045)\end{array}$ & $\begin{array}{l}0.007 \\
(0.040)\end{array}$ & $\begin{array}{l}-0.012 \\
(0.015)\end{array}$ & $\begin{array}{l}-0.001 \\
(0.001)\end{array}$ \\
\hline \multicolumn{9}{|c|}{ Type of higher education institution (Reference Old University) } \\
\hline $\begin{array}{l}\text { 1960's } \\
\text { estabished } \\
\text { Universities }\end{array}$ & & & $\begin{array}{l}-0.045 \\
(0.035)\end{array}$ & $\begin{array}{l}0.028 \\
(0.026)\end{array}$ & $\begin{array}{l}-0.045 \\
(0.036)\end{array}$ & $\begin{array}{l}0.035 \\
(0.025)\end{array}$ & $\begin{array}{l}0.007 \\
(0.007)\end{array}$ & $\begin{array}{l}-0.003 \\
(0.001)\end{array}$ \\
\hline $\begin{array}{l}\text { New (post } \\
\text { 1992) } \\
\text { Universities }\end{array}$ & & & $\begin{array}{l}0.046 \\
(0.023)\end{array}$ & $\begin{array}{l}0.004 \\
(0.020)\end{array}$ & $\begin{array}{l}0.050 \\
(0.024)\end{array}$ & $\begin{array}{l}0.006 \\
(0.020)\end{array}$ & $\begin{array}{l}0.002 \\
(0.006)\end{array}$ & $\begin{array}{l}0.001 \\
(0.000)\end{array}$ \\
\hline HE Colleges & & & $\begin{array}{l}0.062 \\
(0.038)\end{array}$ & $\begin{array}{l}0.017 \\
(0.029)\end{array}$ & $\begin{array}{l}0.063 \\
(0.038)\end{array}$ & $\begin{array}{l}0.035 \\
(0.030)\end{array}$ & $\begin{array}{l}0.000 \\
(0.023)\end{array}$ & $\begin{array}{l}0.002 \\
(0.001)\end{array}$ \\
\hline \multicolumn{9}{|c|}{ Degree Classification (Reference III class, pass or ordinary) } \\
\hline First & & & $\begin{array}{l}-0.044 \\
(0.038)\end{array}$ & $\begin{array}{l}-0.032 \\
(0.032)\end{array}$ & $\begin{array}{l}-0.046 \\
(0.038)\end{array}$ & $\begin{array}{l}0.034 \\
(0.025)\end{array}$ & $\begin{array}{l}-0.007 \\
(0.013)\end{array}$ & $\begin{array}{l}-0.004 \\
(0.002)\end{array}$ \\
\hline II-1 & & & $\begin{array}{l}0.005 \\
(0.027)\end{array}$ & $\begin{array}{l}-0.041 \\
(0.023)\end{array}$ & $\begin{array}{l}0.000 \\
(0.027)\end{array}$ & $\begin{array}{l}0.003 \\
(0.020)\end{array}$ & $\begin{array}{l}-0.021 \\
(0.007)\end{array}$ & $\begin{array}{l}-0.003 \\
(0.001)\end{array}$ \\
\hline II-2 & & & $\begin{array}{l}-0.001 \\
(0.028)\end{array}$ & $\begin{array}{l}-0.036 \\
(0.024)\end{array}$ & $\begin{array}{l}-0.003 \\
(0.028)\end{array}$ & $\begin{array}{l}0.034 \\
(0.025)\end{array}$ & $\begin{array}{l}-0.015 \\
(0.009)\end{array}$ & $\begin{array}{l}-0.002 \\
(0.001)\end{array}$ \\
\hline \multicolumn{9}{|c|}{ Additional qualification (Reference: None) } \\
\hline Phd & & & $\begin{array}{l}-0.085 \\
(0.058)\end{array}$ & $\begin{array}{l}-0.091 \\
(0.056)\end{array}$ & $\begin{array}{l}-0.078 \\
(0.059)\end{array}$ & $\begin{array}{l}-0.073 \\
(0.054)\end{array}$ & $\begin{array}{l}-0.054 \\
(0.023)\end{array}$ & $\begin{array}{l}-0.006 \\
(0.004)\end{array}$ \\
\hline Post-grad. & & & $\begin{array}{l}-0.036 \\
(0.020)\end{array}$ & $\begin{array}{l}-0.089 \\
(0.020)\end{array}$ & $\begin{array}{l}-0.034 \\
(0.020)\end{array}$ & $\begin{array}{l}-0.089 \\
(0.019)\end{array}$ & $\begin{array}{l}-0.056 \\
(0.015)\end{array}$ & $\begin{array}{l}-0.005 \\
(0.001)\end{array}$ \\
\hline $\begin{array}{l}\text { Professional } \\
\text { Qualification }\end{array}$ & & & $\begin{array}{l}0.039 \\
(0.019)\end{array}$ & $\begin{array}{l}-0.003 \\
(0.018)\end{array}$ & $\begin{array}{l}0.034 \\
(0.019)\end{array}$ & $\begin{array}{l}-0.009 \\
(0.018)\end{array}$ & $\begin{array}{l}-0.053 \\
(0.011)\end{array}$ & $\begin{array}{l}-0.006 \\
(0.001)\end{array}$ \\
\hline $\begin{array}{l}\text { Unobserved } \\
\text { Skills }\end{array}$ & & & & & $\begin{array}{l}-0.029 \\
(0.006)\end{array}$ & $\begin{array}{l}-0.037 \\
(0.006)\end{array}$ & $\begin{array}{l}-0.002 \\
(0.003)\end{array}$ & $\begin{array}{l}-0.001 \\
(0.000)\end{array}$ \\
\hline $\begin{array}{l}\text { Pseudo } \mathrm{R}^{2} \\
\text { Observations }\end{array}$ & \multicolumn{2}{|c|}{0.011} & \multicolumn{2}{|c|}{$\begin{array}{r}0.080 \\
2484\end{array}$} & \multicolumn{2}{|c|}{0.092} & \multicolumn{2}{|c|}{$\begin{array}{c}0.1576 \\
2225\end{array}$} \\
\hline
\end{tabular}

Note: All marginal effects are estimated at the mean of explanatory variables. Standard errors, calculated using the Huber/White/sandwich estimator of variance to account for possible heteroskedasticity are reported in parentheses. For models including the unobserved skills variable, the standard errors are obtained by bootstrap with $\mathrm{k}=500$ replications (see Appendix 2). Pre university characteristics include age, gender, ethnicity, school type and social background. Post university characteristics include HE institution missing, region, subject degree missing, class and subject of degree. The base individual is a white female who graduated from a presixties university in Law, with a third class honours degree, does not possess any further qualifications, went to a comprehensive school, with a father who was a manager and lives in inner London. 
Table 6: Different specifications of a model of determinants of hourly pay 6/7 years after graduation for two cohorts: ordinary least squares estimates

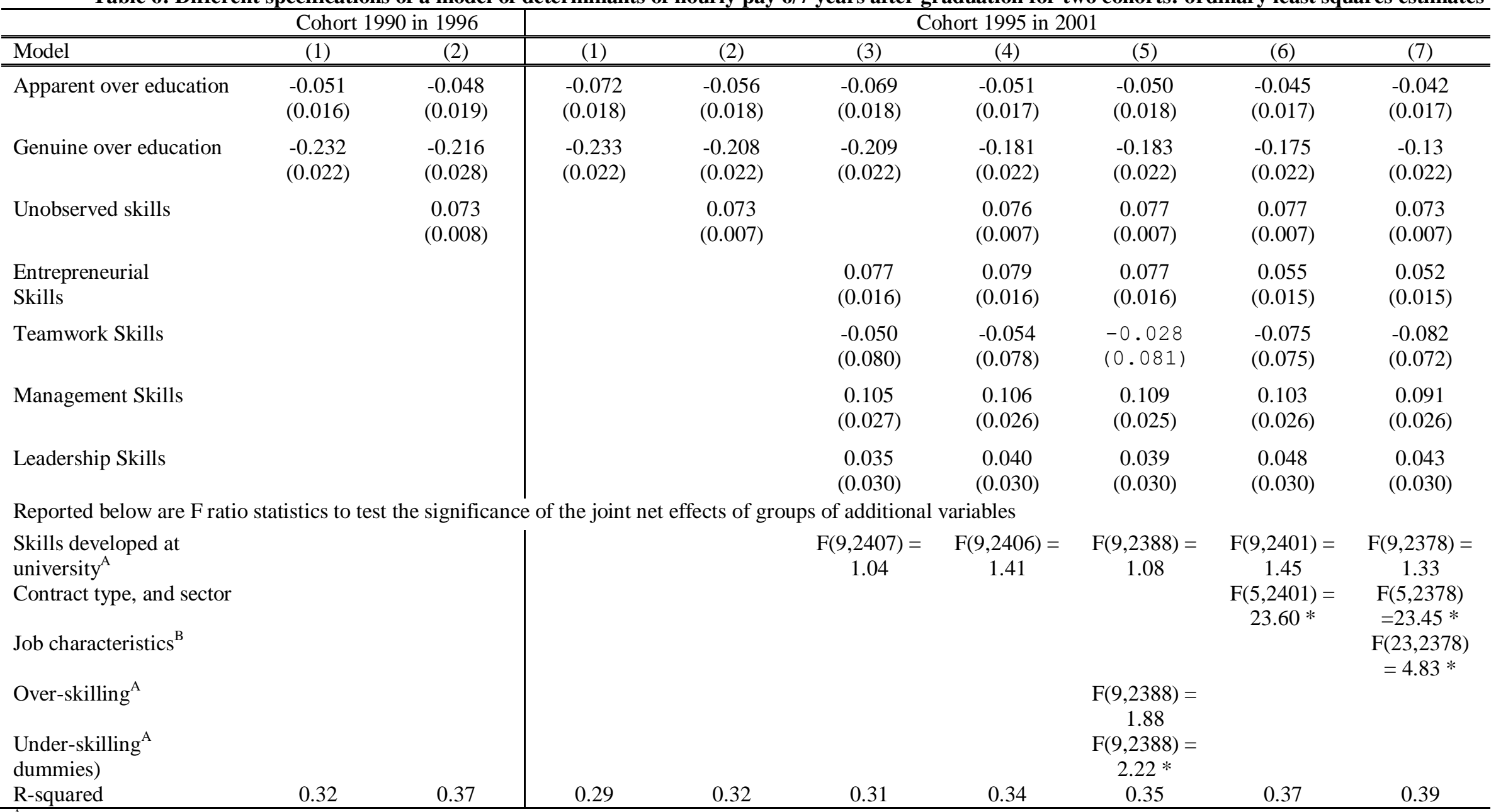

${ }^{\mathrm{A}}$ : Skills include prolem solving, written communication, spoken communication, foreign language, numeracy, basic computer, advanced IT, research,and creativity. Overskilling equals 1 if a skill was developed at university but is not currently used. Underskilling equals 1 if a skill was not developed at university and is currently used.

${ }^{\text {B: }}$ Job characteristics include travel time, responsibility for planning work, computer use, promotion prospects, job satisfaction, satisfaction with career development.

Note: Standard errors calculated using the Huber/White/sandwich estimator of variance to account for possible heteroskedasticity are reported in parentheses. For models including the unobserved skills variable, the standard errors are obtained by bootstrap with $\mathrm{k}=500$ replications (see Appendix 2). The regression is based on 2484 observations and also includes control for gender, social class of parents, ethnicity, the type of schools attended, pre-university credentials, type of higher education institutions, degree grade, subject of degree, additional qualifications as well as employment characteristics such as months of employment and unemployment since graduating, size of employers, and region of residence. Results for the 1990 are based on 2229 observations from the 1996 survey of the 1990 cohort. * denotes significance of F-test at the $5 \%$ level. 
Table 7 OLS, Log hourly pay 6/7 years after graduation, alternative definitions of overeducation

\begin{tabular}{|c|c|c|c|c|}
\hline $\begin{array}{l}\text { Measure of Over- } \\
\text { Education }\end{array}$ & $\begin{array}{l}\text { Degree } n \\
\text { get job }\end{array}$ & equired to & $\begin{array}{l}\text { Less than } \\
30 \% \\
\text { graduate } \\
\text { in job }\end{array}$ & $\begin{array}{l}\text { Elias } \\
\text { and } \\
\text { Purcell }\end{array}$ \\
\hline Cohort & 1990 & 1995 & 1995 & 1995 \\
\hline $\begin{array}{l}\text { Less than } 30 \% \\
\text { graduate in job }\end{array}$ & & & $\begin{array}{l}-0.120 \\
(0.017)\end{array}$ & \\
\hline Degree not required & $\begin{array}{l}-0.110 \\
(0.013)\end{array}$ & $\begin{array}{l}-0.129 \\
(0.019)\end{array}$ & & \\
\hline Modern & & & & $\begin{array}{l}-0.009 \\
(0.024)\end{array}$ \\
\hline New & & & & $\begin{array}{l}0.040 \\
(0.022)\end{array}$ \\
\hline Niche & & & & $\begin{array}{l}-0.030 \\
(0.023)\end{array}$ \\
\hline Not a graduate job & & & & $\begin{array}{l}-0.185 \\
(0.027)\end{array}$ \\
\hline $\begin{array}{l}\text { Unobserved } \\
\text { skills }\end{array}$ & $\begin{array}{l}0.074 \\
(0.010)\end{array}$ & $\begin{array}{l}0.070 \\
(0.008)\end{array}$ & $\begin{array}{l}0.076 \\
(0.007)\end{array}$ & $\begin{array}{l}0.076 \\
(0.007)\end{array}$ \\
\hline Observations & 2151 & 2376 & 2484 & 2484 \\
\hline R-squared & 0.36 & 0.31 & 0.31 & 0.32 \\
\hline
\end{tabular}

Note: All marginal effects are estimated at the mean of explanatory variables and the standard errors reported in parentheses are obtained by bootstrap with $\mathrm{k}=500$ replications (see Appendix 2). The specification of all models is equivalent to models of type (2) in Table 6.

A For the "degree not a requirement" definition, we drop the observations which did not reply to this question or did not know. 


\section{Appendix 1:}

Table A1: Sample selection

\begin{tabular}{llll}
\hline & & \multicolumn{2}{c}{$\begin{array}{l}\text { Characteristics of the remaining } \\
\text { population } \\
\text { Selection criteria applied sequentially }\end{array}$} \\
& $\begin{array}{l}\text { Observations } \\
\text { remaining }\end{array}$ & $\begin{array}{l}\text { First and 2.I } \\
\text { Honour }\end{array}$ & $\begin{array}{l}\text { Months } \\
\text { Unemployed } \\
\text { since graduation }\end{array}$ \\
\hline \hline Original sample & 4502 & 56.36 & 2.06 \\
Current occupation not missing & 3952 & 56.64 & 1.77 \\
How appropriate job is? -not missing & 3900 & 56.78 & 1.76 \\
Employee in 2002 & 3691 & 56.95 & 1.76 \\
Skills not missing & 3278 & 57.50 & 1.73 \\
Living in UK & 3049 & 57.33 & 1.71 \\
Age $\leq 25$ on graduation & 2530 & 57.94 & 1.77 \\
Earnings in first job not missing & 2514 & 57.84 & 1.77 \\
Earnings in current job not missing & 2484 & 57.89 & 1.77 \\
\hline
\end{tabular}




\section{Appendix 2: Methodological Appendix.}

To proxy unobserved characteristics, we estimate an earnings equation for the first job. Mincer (1958) advocated that the appropriate functional form to model earnings function was to $\log$ transform the dependent variable. Based on the human capital theory, the independent variables should include a measure of educational attainment and a quadratic function in experience, to capture the non-linearity of earning growth over the life-time.

Thus the form of the earnings equation adopted is

$\ln y_{i}{ }^{1}=\boldsymbol{\beta}^{1} \mathbf{x}_{i}{ }^{1}+\varepsilon_{i}{ }^{1}$

where $\ln y_{i}^{1}$ is $\log$ of gross annual earnings for individual $i$ in the first job, $\mathbf{x}_{\mathbf{i}}{ }^{1}$ is a vector of worker characteristics that are thought to explain the earnings of graduates in the first job. The estimate of unobserved characteristics is given by the disturbance term $\left(\hat{\varepsilon}_{i}^{1}\right)$ which capture all the unexplained component of earnings including unobserved characteristics of the individual $\mathrm{i}$ as well as job market condition in this first job. The specification of explanatory variables $\mathbf{x}^{1}$ in this paper and empirical results using OLS estimation are given in Appendix 3.

In Figures 3 the distributions of first wage residuals were smoothed using the kernel density estimate formed by summing the weighted values of calculated $\hat{\varepsilon}_{i}^{1}$ using

$\hat{f}=\frac{1}{n h} \sum_{i=1}^{n} K\left(\frac{\bar{\varepsilon}^{1}-\hat{\varepsilon}_{i}^{1}}{h}\right)$

where $\bar{\varepsilon}^{1}$ is the mean of $\hat{\varepsilon}_{i}^{1}$ and

$$
K(z)=\left\{\begin{array}{cc}
\frac{3}{4}\left(1-\frac{1}{5} z^{2}\right) \frac{1}{\sqrt{5}} & \text { if }|z|<\sqrt{5} \\
0 & \text { otherwise }
\end{array}\right.
$$

$K(z)$ is the Epanechnikov kernel function, $h$ is the bandwidth set equal to 0.2 and $n$ is the number of observations over which the density estimate is evaluated $(n=20)$. A similar smoothing procedure was adopted for the raw wage distributions in Figure 4.

In section 4.1 we estimate a multinomial logit model (1) in Table 4 for our favoured definition of over-education. We therefore estimate, 


$$
p_{i h}=\operatorname{prob}\left(Z_{i}=O_{h}\right)=\frac{\exp \left(\boldsymbol{\beta}_{\mathrm{h}}^{\prime} \mathbf{x}_{\mathrm{i}}\right)}{1+\exp \left(\boldsymbol{\beta}_{2}^{\prime} \mathbf{x}_{\mathrm{i}}+\boldsymbol{\beta}_{3}^{\prime} \mathbf{x}_{\mathrm{i}}\right)} \text { for } h=2,3 \text { and } p_{1 \mathrm{i}}=1-p_{2 \mathrm{i}}-p_{3 \mathrm{i}}
$$

where $p_{i h}$ is the probability that individual $i$ will be employed in outcome category $h, \boldsymbol{\beta}_{\mathrm{h}}$ is a vector of coefficients corresponding to the $h$ th response category and $\mathrm{x}_{\mathrm{i}}$ is the vector of socioeconomic individual level characteristics that are thought to explain occupational attainment, as well as an intercept. Models (2), (3) and (4) are defined in a similar way with categories appropriate to the over-education definitions. In the case of (2) and (3) with only two categories it reduces to the simpler binary response logit.. The estimates are calculated by iterative maximum likelihood techniques in STATA 9.2. The results are presented in Table 4 are in the form of marginal effects. The marginal effects are calculated for continuous variables as the derivative of the predicted probability $\hat{p}_{i h}$, evaluated using the mean characteristic vector $\bar{X}$. For categorical variables they are the difference of $\hat{p}_{i h}$ relative to the default category again with other variables evaluated at the mean. The standard errors of the estimated marginal effects are found by the delta method using the parameter estimate standard errors calculated by a bootstrapping procedure similar to the one discussed at the end of this Appendix.

In section 4.2 we estimate earnings equation for the current job where

$$
\ln y_{i}^{c}=\boldsymbol{\beta}^{c} \mathbf{X}_{\mathbf{i}}^{c}+\varepsilon_{i}^{c}
$$

where $\ln y_{i}^{c}$ is $\log$ of gross hourly pay for individual $i$ in the current job, $\mathbf{x}_{\mathrm{i}}^{\mathrm{c}}$ is a vector of worker characteristics that are thought to explain the earnings of graduates for the current job as well as an intercept term. Since $\frac{\partial \ln y_{i}^{c}}{\partial x_{i}^{c}} \approx \frac{\partial y_{i}^{c} / \partial x_{i}^{c}}{y_{i}^{c}}$, the parameters in equation (4), which are reported in Table 5 as log points, can also be interpreted in percentage terms.

In Tables 4, 5, 6 and 7 we have estimated equations (4) and (5) respectively both including and excluding our proxy of unobserved characteristics $\hat{\varepsilon}_{i}^{1}$ estimated from equation (1). We do this because the parameters on observable skills and over-education in equations (4) and (5) are likely to be biased and inconsistent estimators of the true population parameters if these variables are correlated with unobservable characteristics that are also correlated with wages. To demonstrate using equation (5), where for simplicity we assume that there is only one 
variable $x_{\mathrm{i}}^{\mathrm{c}}$ in vector $\mathbf{x}_{\mathrm{i}}^{\mathrm{c}}$. If the disturbance term $\varepsilon_{i}^{c}$ in equation (5) contains unobservable characteristics that we cannot measure, such as motivation, punctuality or fortunate labour market conditions upon entry, which are correlated with $x_{\mathrm{i}}^{\mathrm{c}}$, then the expected value of $\hat{\beta}^{c}$ is given by

$$
E\left(\hat{\beta}^{c}\right)=\beta^{c}+\frac{\operatorname{Cov}\left(x_{i}^{c} \varepsilon_{i}^{c}\right)}{\operatorname{Var}\left(x_{i}^{c}\right)}
$$

Including a proxy for unobservable characteristics in equation (5), in the form of the residuals from the first job wage equation, reduces the extent of this bias and therefore one can estimate current earnings using:

$$
\ln y_{i}^{c}=\boldsymbol{\beta}^{c} \mathbf{x}_{\mathbf{i}}^{c}+\delta \hat{\varepsilon}_{i}^{1}+\varepsilon_{i}^{c}
$$

in order to provide consistent estimates of $\beta^{c}$. The $\delta$ term therefore provides some indication of the effect of unobservable heterogeneity estimated from the first job on current earnings. Given that we have estimated the unknown $\varepsilon_{i}{ }^{1}$ using equation (1) and therefore included the predicted variable $\hat{\varepsilon}_{i}{ }^{1}$ in equation (7), the standard error of this estimated model would be biased. To obtain standard errors, we rely on bootstrapping. The bootstrapping procedure provides a way of estimating standard errors when no other formula is available or when formulas make assumptions that are inappropriate. The procedure involves making $k$ drawings with replacement, of $n$ observations from the $N$ observation dataset. Equation (1) and (7) are then estimated for each of the $k$ draws so that each estimated coefficient in (7) has a distribution of size k. The standard errors for each variable $x$ are then calculated using

$$
\hat{s}_{x}=\left\{\frac{1}{k-1} \sum\left(\hat{\theta}_{x i}-\bar{\theta}_{x}\right)^{2}\right\}^{1 / 2}
$$

where $\hat{\theta}_{x i}$ is the coefficient estimate obtained from each bootstrap sample $\mathrm{i}=1,2 . . \mathrm{k}$ and $\bar{\theta}_{x}$ is the average coefficient for variable $x$ calculated over the bootstrap sample $k$. 
Appendix 3:

Table A3: OLS estimates of first job wage for graduate cohort 1995

Variable

Coefficient

(standard error)

Male

0.049

$(0.012)$

Ethnicity: white

$-0.119$

$(0.030)$

A-level score

0.005

$(0.001)$

Scottish higher

$-0.059$

(0.031)

HE type: Reference- Old University

1960's University

$-0.067$

$(0.022)$

1992 University

$-0.041$

$(0.017)$

HE College

$-0.020$

$(0.026)$

Class of degree: Reference -First

Class of degree: upper second

$-0.068$

$(0.020)$

Class of degree: lower second

$-0.143$

$(0.022)$

Class of degree: third

$-0.170$

$(0.035)$

Class of degree: ordinary or pass

$-0.079$

$(0.039)$

Class of degree: other

$-0.119$

(0.029)

Subject of degree: Reference -: Arts

Humanities

$-0.018$

$(0.041)$

0.085

Language

$(0.048)$

Law

$-0.019$

$(0.050)$

Social sciences

$-0.029$

$(0.040)$

Math

0.077

$(0.045)$

Natural science

0.057

$(0.041)$

Medicine

0.111

$(0.043)$

Engineering

0.103

$(0.044)$

Business

$-0.055$

(0.043)

Education

0.156

(0.043)

Other vocational

$-0.035$

(0.045) 
Interdisciplinary 0.020

Skills learned at university:

$(0.048)$

Problem Solving Skills

Written Communication Skills $\quad-0.061$

$(0.027)$

0.054

$(0.018)$

0.028

Foreign Language Skills $\quad 0.028$

Numeracy Skills $\quad 0.042$

$(0.017)$

Basic computer Skills -0.032

$(0.015)$

0.026

$(0.014)$

$-0.049$

$(0.024)$

0.013

$(0.013)$

0.002

$(0.015)$

teamwork Skills $\quad 0.079$

Management Skills 0.028

$(0.021)$

0.036

$(0.021)$

Parental occupation: Reference-: Base Manager

Parent: technical occupation

Parent: semi-routine occupation $\quad-0.015$

$(0.031)$

$-0.041$

$(0.031)$

$-0.185$

$(0.045)$

$-0.027$

$(0.026)$

School type: Reference- State school

Grammar school

Independent school $\quad 0.050$

Other school type $\quad 0.025$

$(0.029)$ 
Age

0.017

Region of work: Reference- Inner London

Outer London

$(0.005)$

$-0.042$

$(0.024)$

$-0.097$

$(0.021)$

$-0.177$

South West

$(0.025)$

Wales

$-0.156$

$(0.036)$

East Anglia

$-0.133$

$(0.030)$

East Midlands

$-0.110$

(0.029)

West Midlands

$-0.163$

(0.026)

North West

$-0.109$

(0.024)

Yorkshire

$-0.195$

(0.026)

$-0.110$

North

(0.038)

Scotland

$-0.117$

(0.034)

Northern Ireland

$-0.293$

$(0.028)$

Not in the UK

$-0.096$

(0.035)

Constant

9.060

(0.157)

Number of Observations

2512

$\mathrm{R}$-squared

0.24 